\title{
«ПОСЛЕ ПРИЗНАНИЯ И ТОРЖЕСТВА НАЦИОНАЛЬНОГО НАЧАЛА МНОГИЕ ОБЩЕЧЕЛОВЕЧЕСКИЕ ВОПРОСЫ РАЗРЕШАЮТСЯ»: ЕВРОПЕЙСКИЙ ОПЫТ И РОССИЙСКИЙ НАЦИОНАЛЬНЫЙ ПРОЕКТ В РАБОТАХ А. Д. ГРАДОВСКОГО
}

Венгер Н. В. «После признания и торжества национального начала многие общечеловеческие вопросы разрешаются»: европейский опыт и российский национальный проект в работах А. Д. Градовского.

Цель исследования состоит в изучении работ А. Градовского, посвященных проблеме национализма как явления, проявившегося в Западной Европе в XIX ст. Автор изучает, как ученый соотносил вышеназванные явления с ситуацией, сложившейся в Российской империи, определяет место Градовского в контексте общей полемики о российском национальном проекте.

Ключевые слова: русский националистический дискурс, национализм, национальное государство, национальные меньшинства.

Венгер Н. В. «Після визнання і перемоги національного принципу багато загальнолюдських питань знаходять вирішення»: європейський досвід і російський національний проєкт у працях А. Д. Градовського.

Мета дослідження полягає у вивченні праць А. Градовського, присвячених проблемі націоналізму як явищу, яке проявилося в Західнің Свропі в XIX ст. Автор вивчає, як вчений співвідносив вищеназвані явища із ситуацією, що склалася в Російській імперії, визначає місце Градовського в контексті полеміки про російський національний проєкт.

Ключові слова: російський націоналістичний дискурс, націоналізм, національна держава, національні меншини.

Venger N. V. «Nach der Anerkennung und des Triumphes des nationalen Grundsatzes werden viele gesamtmenschliche Fragen gelöst»: die europäische Erfahrung und das russische nationale Projekt in den Arbeiten von A. D.Gradowskij.

Das Ziel der Forschung besteht in der Untersuchung der Arbeiten von A. Gradowskij, die dem Problem des Nationalismus als der Erscheinung gewidmet sind, die sich in Westeuropa im XIX. Jh. offenbart hat. Die Autorin untersucht, wie der Gelehrte die obengenannten Erscheinungen mit der Situation in Verbindung brachte, die im Russischen Reich entstand, bestimmt den Platz von Gradowskij im Kontext der gesamten Polemik über das russische nationale Projekt.

Schlüsselwörter: der russische nationalistische Diskurs, der Nationalismus, der nationale Staat.

Venger N. V. «Many common human issues can be resolved after the recognition and triumph of the national principle": the European experience and the Russian national project in A. D. Gradovsky"s researches.

The purpose of the article is to study the researches by A. Gradovsky, dedicated to the problem of nationalism as a phenomenon that manifested itself in the 19th century Western Europe. The author studies how the scholar correlated the above-named phenomena with the situation in the Russian Empire. N. Venger has found out the place of Gradovsky in the context of the general polemic about the Russian national project. Being rather a scholar, teacher and observer than a politician and publicist, Gradovsky reflected the European experience through the prism of the Russian Empire's history. His Eurocentricity was important due to the fact that the dominant conservative ideology had rejected the western pattern of development for a long time. Most of Gradovsky's articles on national issues were created in the $1870 \mathrm{~s}$ - at the beginning of 1880 s. The scholar was never able to propose a global national project for the Russian Empire. However, projecting European phenomena onto the Russian Empire`s future development, Gradovsky paid attention to the most painful points of the society, which impede the progress of the nation- 
al project's formation and required reforms. The author created his own concept of ethnicity and nation, discussed the issue of the language unification and state religion role as well as advocated freedom of conscience. The topics of serfdom remnants overcoming, the elimination of estates, the emancipation of the peasantry were of great importance for the scholar. Gradovsky also touched on the problem of choosing Russia's national idea, which he associated with Slavism. Supporting decisive actions in Polish uprising suppressing, Gradovsky msisted on keeping a dialogue with the Poles. While solving the German question, he demanded to avoid Russian xenophobia regarding the Russian Germans. It was not clear what the scholar thought about the possibility to create a national state from the totally heterogeneous Russian empire.

Key words: Russian nationalism discourse, nationalism, nation state, national minorities.

Проблема исследования. Со второй трети XIX ст. в России происходило формирование и болезненное признание нового для государства идеологического дискурса - национального проекта, которому следовало предложить и обосновать способ эффективной мобилизации избранной части населения империи с целью нового цивилизационного прорыва. Поиск содержания национального проекта разворачивался в нескольких областях общественного бытия: активно обсуждался в публицистике, проявлялся в государственной политике, активно влиял на социальные движения (являясь своеобразной побудительной эмоцией для масс, далёких от понимания политических процессов) и, наконец, требовал серьёзного теоретического осмысления. Хотя созидателями-сотворцами и реализаторами данного проекта в большей степени являлись представители политикума - практики-консерваторы с различными, часто альтернативными взглядами и понятиями о цивилизационной пользе и целесообразности, свою роль в популяризации и обосновании проекта выполнили теоретики. Некоторые черты либерального проекта национального государства в духе умеренного западничества были представлены А. Д. Градовским. Поскольку Градовский преподавал в университете и сотрудничал с известными публицистическими изданиями Санкт-Петербурга (что было исключительно важно, поскольку национализм с середины XIX ст. фактивно ункционировал в публичной сфере), его опосредованное влияние на политикум и новое поколение российской интеллитенции (прежде всего, его учеников) было несомненным, а позиция преподавателя и мыслителя нашла отклик среди современников, то есть была общественно значимой. Взгляды Градовского, которые и ныне звучат весьма актуально, были исключительно актуальны и оказывали влияние на социальные дискуссии вокруг явлений, до этого частично теоретически осмысленных и воплощённых на практике в некоторых европейских государствах. Цель данного исследования состоит в изучении работ уче- ного, посвященных проблеме национального государства и национализма как явления, проявившегося в XIX ст. в Западной Европе. Нам предстоит ответить на вопрос, насколько близко Градовский соотносил вышеназванные явления с ситуацией, сложившейся в России, и каковыми были рефлексии его понимания о европейском настоящем применительно к развитию национализма в Российской империи, гармонизации межэтнических противоречий и полиэтнической структуры государства. Для нас также важно определить место Градовского в контексте общей полемики о российском национальном проекте, которая разворачивалась в государстве в последней трети XIX ст.

Источники. А. Д. Градовский проявил себя как работоспособный, активно пишущий и публикующийся автор. Он являлся ученым представителем государственной школы, который занимался теоретической разработкой проблем отечественного правоведения и истории Российской державы, а также вёл преподавательскую деятельность. Общее собрание сочинений мыслителя, увидевшее свет после его смерти в 1899 г. и издававшиеся около десятилетия, составляет девять томов оритинальных трудов, которые демонстрируют как многообразие, так и последовательность научных интересов ученого [31]. Большинство исследований по интересующей нас проблеме собраны в VI томе собрания сочинений. Эти работы, написанные преимущественно в 1870-1880-х гг. («Современные воззрения на государство и национальность» (1872); «Государство и народность. Опыт постановки национального вопроса» (1873); «Национальный вопрос» (1877), «Государство и Церковь в Пруссии. Пятнадцать лет культуркампфа» (1886), а также другие исследования автора составили источниковую базу данной статьи [32].

Историография проблемы. Значимость теоретического наследия Градовского, его педагогической и общественной деятельности были признаны современниками. Первыми биографами А. Д. Градовского были 
Б. Б. Глинский [1] и И. М. Свешников [43]. Вскоре после смерти ученого был опубликован указатель его трудов [3]. Первыми авторами, представившими общий обзор наследия ученого, являлись И. Я. Фойницкий, Н. М. Коркунов, А. Ф. Кони [47], И. А. Ивановский [39]. Дальнейший интерес к творчеству А. Градовского возник лишь в конце XX ст. Различные исследования его научного наследия представлены преимущественно современными российскими гумманитариями А. Ф. Замалеевым [38], И. И. Гуляком [37], Т. Е. Плященко [42], Т. В. Брояко [5]. Их работы отражают отдельные тематические направления многогранной деятельности Градовского, лишь коротко касаясь его исследований в области теории национального государства, национализма и прикладных проблем межэтнического взаимодействия в контексте концепции национализма, исследование которых составляет комплекс задач данной публикации.

Градовский в кругу российских публицистов - создателей и оппонентов «национального проекта». Противоречия 1860$\mathrm{x}$ гг. сформировали тематическую платформу или (как образно высказался А. Миллер) «репертуар дискуссий» постреформенных десятилетий, в которых голос А. Д. Градовского прозвучал весьма выразительно. С середины XIX cт. понятия «нация» и «национализм» в большей степени приблизились к современному пониманию [41]. В дискурсе о нации и национальном проекте речь шла о том, какой может быть российская (или, как вариант, русская нация), как её следовало формировать и затем использовать для усиления государства и его позиций в мире и, прежде всего, на фоне европейского противостояния. В данном комплексе дискуссий Градовский выступил более всего как профессионал, ученый-теоретик, а лишь затем как публицист. В 1862 г. Градовский закончил Харьковский университет со степенью кандидата права. Некоторое время он служил чиновником особых поручений при местном губернаторе, но с 1866 г. карьерная биография ученого связана с Санкт-Петербургом, где. он защитил магистерскую диссертацию на тему «Высшая администрация России XVIII ст. и генералпрокуроры». Квалификационная работа была выполнена в области исторического правоведения при кафедре государственного права Санкт-Петербургского университета. С этого момента началась преподавательская деятельность А. Д. Градовского. Выполняя академические обязанности, разрабатывая новые курсы и излагая свои знания и мысли на бумаге (в том числе и с дидактической целью), Градовский показал себя, прежде всего, как репрезентант уже признанных в Европе научных проблем, тем и их интерпретаций. Кроме преподавательской деятельности, он также являлся постоянным сотрудником изданий «Голос» и «Русская речь» [10], с которыми связан самый продуктивный период его журналистской деятельности (1870 - начало 1880 -х гг.) [1].

Теоретические разработки А. Д. Градовского явились продолжением и одновременно более либеральным осмыслением темы, поднятой после 1848 г. Ю. Ф. Самариным, К. Д. Кавелиным, М. Н. Катковым, которых Б. Б. Глинский несколько патетически назвал «типичными представителями зари просвещенной свободы». Оценивая вклад публицистов в развитие общественно-политической мысли, биограф также заметил, что в начале их деятельности, несмотря на некоторое различие в убеждениях мыслителей, «их тесно соединяло чувство глубокого поклонения реформам Александра II, общее служение до последней минуты своей жизни началам, указанным в Манифесте 19-го февраля 1861 г.» $[1$, c. 539]. Хотя в среде российских консерваторов либерализм называли «отречением от народности» [29, с. 354], для Градовского (приверженца европейских ценностей и последователя актуальных европейских воззрений) тема национализма была близкой и неслучайной ещё и потому, что, как он утверждал, «начиная с 1815 г. во всей Европе национальные движения были связаны с движениями либеральными». После первого польского восстания этническая ситуация в государстве стала объектом осмысления и критики как политиков, так и публицистов. В её контексте на общественном уровне вызревал национальный проект. С 1848 г. к дискуссии политиков (например, П. И. Кёппена) о социальной справедливости и привилегиях, предоставленных окраинным территориям и отдельным этническим группам, присоединился славянофил Ю. Ф. Самарин, который представил характеристику немецкой проблемы в Остзейских губерниях [7]. Характеризуя ситуацию на окраинах, политики и чиновники вели споры о российской нации, включении / исключении отдельных этнических груп в тело нации, социальной справедливости, локальных национализмах (разумеется, в соответствующей их эпохе терминологии). Обосновывая путь исключения из проекта инородщев, российские публицисты и политики уже в 1840-1860-х гг. сформулировали следующие тезисы, обосновывавшие их позицию: 1) был поднят вопрос 
о привилегированном положении отдельных этнических групп (например, колонистов), несовершенстве внутренней политики относительно окраин; 2) призывали к реформированию и правовой унификации, уравниванию прав русских крестьян с нетитульными этносами; 3) речь шла и об опасности германизации, полонизации и т. д. Например, И. С. Аксаков именовал немцев - жителей Юга и Запада империи - «паразитами и чужеядью», которые живут замкнуто, развивают племенной инородческий патриотизм и сепаратные настроения на окраинах [Там же]. Были высказаны представления о «внутренних врагах» и «верном оплоте», «государствах в государстве», безмерном расширении землевладения в среде нерусскоязычного населения, отсутствии у него преданности и лояльности; 4) М. Н. Катков предупреждал своих читателей о том, что некоторые этносы (например, немецкий) имеют высокий потенциал культурного влияния. Он упоминал евреев, которые в религиозной практике использовали немецкие тексты [8]; 5) звучали обоснования политики языковой унификации; 6) имели место призывы к консолидации подданных против внутреннего врага. Таким образом, по объективным причинам, вызванным, например, польскими восстаниями, «мобилизация» российской нации (известное высказывание Б. Андерсена) происходила по антагонистическому сценарию «союза против» инородцев, или, как формулирует А. Миллер, по сценарию «исключения».

Несмотря на то, что деятельность Градовского приходилась на реформационный период, а его взгляды в некотором смысле отличались от позиции бывших либералов, которые c 1870-х гт., как заметил сперва Б. Глинский, а затем и современные исследователи, резко изменили свои позиции, разуверившись в реформах и пополнив лагерь консерваторов, он с большим уважением относился к Ю Ф. Самарину и другим оппонентам противоположного лагеря. Градовский позитивно оценивал принципиальную позицию чиновника в Остзейском вопросе, на этапе выработки проекта ликвидации крепостного права $[1$, с. 539] и называл его «горячим адвокатом жизни» [4, с. 107]. Принимая всё более правую идеологию, М. Катков в своих «Московских ведомостях» выступал против либерализма и газеты «Голос», неоднократно высказывался против идей А. Градовского. Ему вторил и И. С. Аксаков, который, тем не менее, с определённой симпатией относился к ученому, а некоторое время считал его «человеком своего лагеря» $[1$, c. 545$]$. В свою очередь Градовский, ана- лизируя публикации газеты «Русь» и лично И. С. Аксакова, отмечал, что, несмотря на разность позиций, они достойны внимательного прочтения: «Каким убеждением и какой страстью проникнуты строки, исходящие из-под его пера!» [18, с. 401]. Фиксируя несогласие с Аксаковым по ряду вопросов, учёный признавал, что в отдельных работах публициста по истории российской государственности присутствуют весьма важные заключения. С М. Катковым Градовского объединял также интерес к немецкой философии [44, с. 541].

Как педагог и теоретик Градовский осознавал свою миссию. Будучи либералом, критикуемый консерваторами и поздними славянофилами, он балансировал между ними и западниками, которые, как утверждают современные исследователи, с 1870-х гг. были склонны объединиться вокруг консерватизма $[36$, с. 246]. Слагая «оду» произведениям Фихте, ученый полагал, что наука должна служить обществу, а полярность мнений не является причиной для взаимной неприязни, поскольку задача науки состоит в изобретении для общества более конструктивных путей развития, как это случилось в Германии, где тот же «философствующий дух (творчество философа) указал народу на живые источники его национального развития, его творчества и силы в будущем» [13, с. 157]. Градовский желал конструктивного обсуждения, и его умение дискутировать было таковым, которое, как говорил П. Б. Струве, не уничтожает противника, а является «полемикой ради раскрытия всех схождений и расхождений мысли, полемикой по существу» [45, с. 59]. Именно реформы, а не консервативный путь развития А. Д. Градовский считал единственным прогрессивным направлением развития России. По этой причине, как сообщает знавший его лично Б. Глинский, после событий 1 марта 1881 г., которые положили конец реформам, Градовский целиком ушел в академическую деятельность, не опубликовав в оставшиеся восемь лет жизни ни одной значимой работы в духе национал-либерализма [1, с. 549].

Общий взгляд на проблему национализма и национального государства в работах Градовского. Ознакомление с теорией национализма в версии А. Д. Градовского обнаруживает связь современных конщепций с идеями, озвученными в далёком XIX ст. как европейскими, так и российскими мыслителями. Постановочными в этом ключе следует рассматривать его работы «Национальный вопрос в истории и литературе», «Национальный вопрос», «Реформы и народность», «Со- 
временные воззрения на государство и национальность» и другие, где ученый стремился, как он писал, «исследовать значение национального подхода в современной политической жизни» [32]. Приступая к анализу проблемы, следует сразу же подчеркнуть, что используемая Градовским терминология и её контентные характеристики существенно отличаются от современных. Определённые сложности для понимания идей ученого возникают, прежде всего, с ключевыми категориями, важными для нашего исследования - понятиями «нация» и «этнос». В работах Градовского им наиболее соответствуют значения «народность / политическая народность» (в современном понимании «нация») и «раса / естественная народность / племя» («ЭТнос») [16, с. 13].

Мыслитель связывает формирование нации и новый виток в понимании национального вопроса (то есть вопроса о нации, национальном государстве) как в Европе, так и в России с эпохой либерализма. Данное явление развития политий проявляется по мере того (как рассматривает Градовский применительно к России и через призму его позитивного отношения к реформам Александра II), как происходит эмансипация общества (как это случилось в Италии и Франции): «Без сознания своей собственной личности не может быть сознания и личности народной, следовательно, и возможности служения родине в духе народном» $[35$, с. 460$]$. В одной из своих работ ученый утверждает: «В массе бесправной нет единения, в ней напротив идёт все вразброд» [29, с. 372]. При этом национальный вопрос для отдельных государств возникает в соответствующее их развитию историческое время. Градовский отмечает, что национальность не есть нечто, данное народу сразу в готовом виде: «Народ зарабатывает, завоевывает ее, как отдельный человек, борьбою и трудом достигает самостоятельности и оригинальности». И затем резюмирует: «Так, под влиянием долгих исторических испытаний образуется национальный тип, и в этом типе воплощается одна какая-либо сторона общечеловеческих стремлений, свойств ума и фантазии» [35, с. 402]. Апелируя к примеру объединённой Германии, он показывает, что «нравственный задаток... был заложен ещё в то время, когда главный её оплот Пруссия - была раздавлена под французским владычеством» $[15$, с. 225$]$. При этом ученый подчёркивает, что идея народностей (наций) - исторически нова, относится к XVIIIXIX ст. [Там же, с. 238]. Соотнося свои мысли с определённым периодом, автор обозначил факторы исторического влияния на развитие национальных процессов: «Народность образуется под влиянием известных благоприятных условий и замирает, чахнет при наличности других обстоятельств» $[29$, с. 364]. Среди геополитических (внешних) факторов влияния были названы иноземные завоевания, феодализм и, по Градовскому, применительно к Европе - католицизм, то есть политические и культурно-религиозные процессы, которые в европейском масштабе способствовали выработке национальной самоидентификации и дифференциации или же тормозили данный процесс [15, с. 240].

Развивая теорию народности, мыслитель указывает, что развитие народностей (наций) сдерживалось двумя факторами: политическим разделением племени, его раздроблением (в условиях феодальной системы), а также, опять же для Европы, общеевропейским «искусственным единством католицизма». Из этого тезиса следуют два вывода. Во-первых, народность - это больше чем племя («Не должно смешивать народность с племенем. Народность может составиться из многих ассимилированных племён (народов).), и возникает на базе племени в определённых исторических условиях»). А во-вторых, ученый утверждал, что папство, которое насаждало католическую идеологию в Европе, сдерживало процессы племенной самоидентификации и задерживало развитие народностей [Там же].

Что же способствовало развитию народностей / наций? Это факторы двух уровней: 1) естественно-исторические, формирующиеся под влиянием географических, климатических, исторических условий («ассимиляция - уподобление племён» $[15$, с. 246], возникновение новоевропейских языков, нравственные и умственные особенности племени (нечто сходное с национальным характером), склад семейных отношений); 2) культурно-политические (движение общин, эмансипация низпих классов, протестантизм и постепенное развитие религиозной свободы) [Там же]. Протестантизм характеризуется автором как донациональные локальные религии, которые разрывали «путы» католицизма и способствовали процессам местной самоидентификации и сплочению народов определённых государств. Ко второй группе факторов относится также «совокупность тех общественных стремлений, симпатий и антипатий, идеалов, нравов, которые выработались и окрепли в народности в течение долгой исторической жизни и выразились в государственных учреждениях, в науке, поэзии, искусстве» $[15$, с. 240$]$. 
Градовский также признаёт, что нация может состоять из разных «племён» (этносов), которые сближаются в результате проживания на одной территории и совместной трудовой деятельности: «Из бриттов, англо-саксов и норманн образовались англичане. Франки, бургунды, вестготы, вместе с романизированными галлами сливаются в единую франщузскую нацию, и из прежнего многоязычия выступает французский язык, на котором будут говорить Рабле, Монтэнь...» [15, с. 246]. Данные племена некогда были разобщены и завоёваны друг другом, но в результате исторического развития они цивилизационно сблизились, ассимилировались в рамках государства, построили города и создали общую буржуазию (читай, промышленную или другую модерную) элиту [Там же]. Пробел в теоретическом осмыслении народности (нации) состоит в том, что Градовский, демонстрируя факты, которые предшествуют основанию нации, не поясняет, что же является пусковым механизмом национального чувства (то, что Б. Андерсен назвал «изобретением нации»). Однако некоторые догадки в направлении сходного заключения им таки были сделаны: «Появившаяся народность «неизбежно вырабатывает два понятия... понятие о своём единстве и своей независимости» [33, c. 51]. И далее речь идёт о коллективном совместном сотворчестве: «Понятие о единстве построено на сознании полной общности интересов и оригинальности общей всем творческой силы; требование независимости вытекает из осознания своего права на проявление этой творческой силы в самостоятельной культуре, в оригинальном историческом развитии» [Там же]. Таким образом, нация строится из отдельных составляющих, объединённых идентичностью и некоторым творческим актом.

Обоснование национализма и национального многообразия базируется у А. Д. Градовского на аналогии с тем, что «каждая народность», будучи макроединством, является «нравственной и свободной личностью (единицей человечества), имеющей право на самостоятельную историю, следовательно, на своё государство». Это разнообразие - коренное условие правильного хода общечеловеческой цивилизации. При этом «человечество в целом» представлено Градовским как система разнородных человеческих групп, заявляющих своё право на самобытное существование» [17, с. 4]. Либерализм Градовского несёт на себе налёт идеализма и позитивизма. Он признаёт существование некоторой всеобъемлющей человеческой цивилизации, для ко- торой важна каждая народность - «каждая личность», самобытность которой подавлять непозволительно: «Лишить человечество его разнообразных органов значит лишить его возможности проявить во всемирной истории всё богатство человеческого духа... Однообразия культурных форм противны всем условиям человеческого прогресса» $[17$, с. 14]. Он полагает, что от поликультурного разнообразия человечество только выигрывает: «Каждый народ в своей истории выражает и доводит до определённого результата только некоторые стороны всеобщего содержания народного духа. Общечеловеческое начало есть начало хоровое, в котором каждому голосу, каждому звуку должно быть место» $[15$, c. 233$]$.

В сборнике «Национальный вопрос в истории и в литературе» (1873) [16] ученый поясняет, что национальные различия в мировом сообществе обусловлены объективным развитием истории, а «разнообразие национальных особенностей есть коренное условие правильного хода общечеловеческой цивилизации», которая является совокупностью специфического духовного и экономического опыта различных народов. Следовательно, нужно не подавлять и сглаживать национальные различия и особенности, а наоборот - создавать условия для органичного и самобытного существования и развития национальностей. Важнейшим из этих условий он считал «политическую самостоятельность народа», наличие у него национальной элиты, образование национальных государств.

Разработка понятия этноса в мировоззрении Градовского. Как следует из вышесказанного, народность (как аналог нации) для теоретика формировалась из различных этнических субстратов (или, в его терминологическом поле, племён, естественных народностей).

Чем же этнос / племя отличается от народности / национальности? Этнос более «подчинён законам природным (скажем, природно-антропологическим, а не политикогенетическим): язык, религия, зависит от «географических, геологических, ботанических и т. п. особенностей страны, сделавшейся местом оседлости народа». Племена формируются экономическими условиями, традициями разделения труда, социальной структуры и т. д. [33, с. 47]. Хотя в условиях нового времени национальные государства становятся всё более обычным и закономерным явлением, не каждое племя способно сформировать свою народность, а следовательно, и национальное государство: «Особенности племе- 
ни и языка суть только зародыши, возможность народности. Сила и устойчивость этих особенностей испытываются историей, в течение которой обнаруживается, способно ли племя к творчеству и самобытной цивилизации - следовательно, к образованию народности) $[33$, с. 36$]$.

Естественная народность, как констатирует мыслитель, обладает своим характером (в современном понимании - национальным характером) $[17$, с. 14]. Особенности «характера» проявляются в форме традиций и социальных институтов («нравов и учреждений»). Данные характеристики передаются традиционным способом, в процессе бытования отдельной личности в рамках своего социума: «Она [личность] наталкивается на них каждую минуту: в семейной жизни, форме собственности, характере сельского хозяйства и общественного управления, в песне рабочего и романе из национальной жизни», церковной жизни и школе $[15$, с. 260-261]. И далее: «Каждый [индивид] невольно осознаёт, что только в общении со своим народом он есть нечто самобытное и творческое... Попробуй оторвать человека от его народа и вы увидите, как иссякнут самые живые силы, самое могущественное творчество» [Там же].

Признавая уникальность каждого этноса, Градовский выступает против деления народов на исторические и неисторические как предрассудка, от которого следует отказаться. Градовский критикует Фихте и его теорию «призванных» народностей, которая выстроена на понятии единства и исключительности цивилизации, её идеал - всемирное государство, наполненное общечеловеками, скроенными по образшу преобладающей расы $[13$, с. 110]. Градовский предостерегает: «Подчинение всех рас одной всеспасающей цивилизации также пагубно действует на международную жизнь, как всеспасающая административная централизация - на внутреннюю жизнь страны» $[17$, с. 15]. Вместо этого он констатирует: «Народное творчество - вот последняя цель, без которой не может бать достигнуто совершенство рода человеческого. Убить творческую силу народа - всё равно, что убить силу личной предприимчивости...» $[13$, с. 110$]$.

Градовский отвергает идеи социального дарвинизма, полагая, что в формировании глобальной цивилизации «никакой народ не может сделаться представителем всего человечества» [34, с. 268], а «цивилизация, оставаясь общечеловеческою, явилась продуктом цивилизаций многих народов - французского, итальянского, немецкого, английского...»
[34, с. 269]. И далее: «В самом деле, возведите в принцип право завоевания и насилия в отношениях народных, и тогда спросите, во имя какой логики можно требовать признания неприкосновенности отдельной человеческой личности? Если вы пожелаете разделить народы на призванные к господству и предназначенные к рабству, то не будет ли актом высочайшего лицемерия провозглашать равноправность отдельных человеческих единиц?» [12, с. 589].

Почему возникают национальные государства? Внешним проявлением требования независимости нации является, по Градовскому, стремление создать свою собственную государственность - «политико-юридическую форму народности» $[17$, с. 16]: «Каждая народность [нация], то есть совокупность лиц, связанная единством происхождения, языка, цивилизации и исторического проплого (комплекс естественно-природных и политических процессов), имеет право образовывать особую политическую единишу, то есть государство» $[17$, с. 13]. Государство является «средством охранения и укрепления народности» $[15$, с. 263], и, «добиваясь своего государства, нация в сущности ищет средства обеспечения своей самобытности... Без самостоятельности политической она утратит возможность самостоятельной культуры, сделается простым служебным материалом для другой народности, откажется от всякого исторического развития) [Там же].

Следовательно, продолжает Градовский, складывание национальных государств - органичный результат развития нации, а посему наблюдаемых в XIX ст. явлений политической истории Европы следует не опасаться, а ожидать: «Для всякого неослеплённого человека ясен тот факт, что принцип национальностей провозглашён на западе Европе самым торжественным недвусмысленным образом, что всякие задержки, поставленные для его развития, оказывались тщетными» $[12$, c. 589$]$.

Важен тезис Градовского о том, что в национальной среде и на национальной почве формируется и возрастает элита - личности, чья харизма обеспечивает прорыв нации к новым высотам: «Чем был бы германский народ без Лютера, Лейбница, Лессинга, Гумбольта?...В этих людях определился германский дух, через них получил он почетное место в общечеловеческой цивилизации» [29, с. 371]. Рассуждая о роли Фихте, Градовский подчеркивает, что его деятельность «как представителя национального движения в Германии, была направлена к эмансипации германского созна- 
ния из-под чисто чужеземной цивилизации» $[13$, с. 124]. Фихте требовал от своего народа движения вперёд, не в смысле приобретения новых территорий, но в контексте создания важных основ для общественной и государственной жизни: «Он думал вызвать разумную сознательную веру в назначение германского народа» [13, с. 122].

Какие характеристики являются атрибутивными особенностями (национального) государства? Это государство, чьё общество отличается определённой сплочённостью и гражданским сознанием, внутри которого «политическая власть должна быть органически связана с народом, и наоборот, каждое национальное общество, способное к самостоятельной исторической жизни, имеет право образовать свою политическую форму, согласно своим стремлениям и потребностям». В рамках данного определения национального государства содержится понимание нации как социальной гиперструктуры в рамках одного государства, объединённой политической и экономической жизнью.

Ученый отвечает на вопрос, почему понятие национального воспринимается в Европе скорее негативно, чем нейтрально, и в чём может состоять опасность национального государства для других политий? В работе «Возрождение Германии и Фихте Старший» [13] Градовский обращается к опыту недавно консолидированной, как он говорит, «чуждой, и во многих отношениях, враждебной нам народности» [13, с. 108]. Фихте важен для его исследований как мыслитель, который поднял «вопрос о национальности на степень вопроса философского, общечеловеческого, сделал из понятия национальности принцип философии истории» [Там же]. Для Фихте вопрос о нации имеет два проявления: практическое («грубое, насильственное», проявляющееся в политике) и научное (философское, теоретическое). Руководствуясь чисто немецкими задачами, философ в начале XIX ст. утверждал, что в практической форме - это вопрос о превосходстве одного народа над другим: «Если такой народ выходит из изолированности, то исключительно с целью всемирного преобладания... Исчезновение, поглощение таких народностей - конечная цель такого взгляда; презрение «призванной» народности к непризванным - естественная форма их отношений... Военное могущество - единственное средство осуществить такую национальную цель» $[13$, с. 109]. Рассуждая таким образом, Градовский, сам того не желая, создаёт теоретическую базу для германофобии не только в геополитическом дискурсе, но и во вну- тренней политике российского государства, поддерживая рассуждения о «государстве в государстве». Знаменитое представление о российских немцах как о пятой колонне сводилось не к тому, что они представили свой концепт окраинного национализма, а в подозрениях российского общества о том, что российские немцы были включены в процессы демобилизации германской нации. Очень опосредованно Градовский говорит о том, какую потенциальную угрозу Германия несёт для Российской империи, поскольку данная нация ставит себя выше славянских народов: «Мы слышим о том, что славянский мир осуждён на вечное прозябание, что латинская раса отжила свой век, что единственное спасение европейского материка заключается в безусловном подчинении диктатуре «призванной расы» [Там же]. В основе этого, комментирует Градовский, находится идея «грубого преобладания» нации и её национального государства, основанного на военной силе.

Подлерживая теорию национального государства и считая, что в его рамках разрешается большинство вопросов общества и нации, Градовский противоставляет их империям. Он предоставляет некоторые замечания о тех болевых точках, которые несут в себе империи - комплексные политии, возникновение которых связано с предшествующим историческим периодом. Поскольку империи создаются преимущественно насильственным путём, мыслитель именовал их «искусственными государствами». Форма их образования несёт в себе неизбежные последствия для внутренней политики и режима относительно нетитульных племён / этносов: «Созданные обыкновенно насилием, они [имперские государства] должны направить все средства на сохранение и поддержание своего искусственного единства. Они, в силу вещей, должны бывают подавлять всякое свободное проявление жизни и даже мысли. Развитие свободы кажется им опасным потому, что оно может напомнить насильственно сплоченным народностям об их правах. Признание даже административного самоуправления кажется невозможным, потому что за ним может явиться требование самостоятельности политической... Усиление соседа вызывает тревожные опасения» $[17$, с. 27].

Проблема межэтнических отношений в империях. Межэтнические противоречия являлись важнейшей проблемой Российской империи в условиях социально несбалансированной модернизации. Предсказывая законы взаимодействия титульных и нетитульных этнических групп в пределах империи, 
Градовский комментирует: в рамках империи «самостоятельное культурное развитие народа (этноса), вошедшего в состав другого государства, приостанавливается», поскольку в такой ситуации народ «делается служебным материалом для других рас» [17, с. 15]. В такой ситуации «подчинённые (у Градовского, в значении завоёванные $-H$. $B$.) этносы должны будут принять цивилизацию чужого народа, то есть отказаться от своей индивидуальности, сделаться другим народом. Но не каждый народ способен на такую жертву» $[17$, с. 16$]$. В качестве примера ученым проводится анализ положения славян в Австро-Вентерской империи: «Среди господствующей народности (немецкой) славяне находятся в положении «варваров», обязанных принять высшую культуру, то есть чужой язык и чужие обычаи». И лишь только «освобождение от немецкого ига... даст... возможности [им] сказать своё слово во всемирной цивилизации!» [Там же]. В рамках империи «презрение победителя к побеждённым не знает границ... Bce насилие над побеждённым оправдывается и даже возводится в степень политической необходимости». Для сглаживания такого рода противоречий должно пройти много времени, и это вредит крепости и стойкости самого государства. Почему Австрия, которая, как считает учёный, имеет хорошую либеральную конституцию, готова развалиться каждую минуту? Почему «мои народы» (так говорят Габсбурги) «употребляют свободу слова для распространения идей, противных единству столь просвещённого государства»? Не потому ли, что все они чувствуют, в какой степени они «не дома», не в своём государстве...» $[33$, с. 106]. Такое лоскутное государство должно поддерживать своё существование или конституциональными уловками, или армией, то есть либо обманом, либо насилием. А в другой своей работе он замечает: «Болгарин никогда не простит турку своё историческое прошлое» $[17$, с. 23]. Таким образом, отдельные народы полиэтнического государства, «сохраняя воспоминания о своей самостоятельности, беспрерывно стремятся к ней». При этом в таких государствах власть опирается лишь на одну из народностей, являющуюся «преобладающей» (доминирующей) $[17$, c. 7$]$.

Что означал данный тезис для практиков созидателей теории российской нации? Только одно: на пути формирования в данной империи единой нации по сценарию включения в проект или же (в условиях неравноправия отдельных этнических групп) исключения из него, неизбежно возникнут трудности (по- скольку «завоевательное начало» всегда будет видоизменять свои формы, в том числе и на этапе сосуществования после завоевания).

Градовский выступает против политики насильственной ассимиляции этнических групп как метода, используемого для объединения и усиления империи («Мало ли племён погибло, вошедших в состав других, более сильных народностей!» [29, с. 371$])$. В современных ему условиях данный путь не являлся возможным, особенно относительно отдельных этнических групп - европейских национальных меньшинств, обладавших сильной культурной устойчивостью: «...Вряд ли дело объединения совершится, если слава одной народности, входящей в состав искусственного государства (в значении империи), составляет позор и страдания другой, если всё прошедшее одной части государства заставляет её ненавидеть другую» [17, с. 23]. Данная оценка ассимиляции и взаимоотношений титульной нации и национальных меньшинств вполне применима к оценке российской ситуации.

Может ли полиэтническое государство быть успешным и консолидированным? В качестве одного из показательных положительных примеров философ использует Швейцарию, которая объединяет представителей трёх народностей, говорящих и думающих на разных языках. Суть феномена кроется в правовом устройстве общества, которое обеспечивает равноправие национальньх диаспор крупных государств: швейцарские немцы, франшузы и итальянцы не стремятся примкнуть к своим национальным государствам, поскольку «слишком любят свою конституцию: эта конституция как бы их общее отечество» $[17$, с. 23$]$. В Швейцарии, утверждает автор, отсутствует «господствующая народность, привилегии которой тяжелым гнётом ложатся на народности подчинённые». Данная полития является федеративным государством, в условиях которого вполне обеспечено сохранение этнической идентичности представителей отдельных наций. Видимо, одним из первых Градовский заметил, что нейтральный статус государства существенно уменьшает внешнее влияние на входящие в него диаспоры со стороны их метрополий $[17$, c. 24$]$.

Возвращаясь к теме национального государства и полагая, что каждая эпоха имеет «принцип» («Принцип каждой эпохи может быть лучше всего понят на примере того народа, который в данную эпоху стоит во главе цивилизации вообще - народа, выражающего мысль эпохи» $[13$, с. 135]), Градовский подни- 
мает важнейший вопрос из области морали о том, имеет ли право такой геополитически харизматичный народ (как немецкий у Фихте) на культурное порабощение более слабого и малочисленного? Обращаясь к примеру Германии, ученый делает вывод, что для жизни народа равно важны и внешняя, и внутренняя свобода, в то время как экспансия, физическое насилие и завоевания задерживают творческую силу народности. Другими словами, сам народ способен поработить себя идеей экспансии и «высшей цивилизации». Такой путь консолидации нации Градовский отвергает, считая его «пленением духовным», которое ограничивает внутреннюю свободу бытования нации [13, с. 111].

Как известно, всякая теория о нации находит внутреннюю рефлексию. Она проявляется, например, в так называемом проекте нации, который, как правило, не является законодательно признанным документом, изложенным на бумаге, а отражается в сознании элит. Его, как правило, обсуждают политики и публицисты, включая либо исключая отдельные этнические группы из представлений о членстве. В чем состоит проблема внутренней ситуации, которая сложилась в Российской империи при формировании проекта? Рефлексируя проблему межэтнического взаимодействия опосредованно в ряде своих статей, Градовский выступает против всяческой этнофобии (англомании, галломании), а также «германофобии, господствующей в некоторых сферах [российского] общества» [19, c. 175]. Признавая присутствие негативных настроений по отношению к представителям отдельных национальных меньшинств (современное понятие), он задаётся вопросом о том, какими же должны быть отношения между отдельными этническими группами (титульной и иноэтничной, возможно диаспоральной), если их положение и уровень развития в рамках политии не соответствует градации главенствующего и подчинённого компонентов (русские - титульная нация, имели меньше прав, чем немцы-колонисты). Градовский призывает испытываюших ресентимент русских гармонизировать проблему через творческое взаимодействие и взаимное культурное обогащение: «Взять, что можно, от других на правах свободного обмена, coхраняя полную свою самостоятельность - вот условие народного существования» [13, с. 111].

С другой стороны, рассматривая влияние отдельных этнических групп на культурное развитие российского общества, Градовский, будучи патриотом, выступает против «необоснованных заимствований». Должно быть взято только то, что принадлежит к разряду важного общечеловеческого, а остальное «должно быть предоставлено творчеству каждого народа» $[19$, с. 175]. Заимствование должно стать лишь промежуточной «работой» культурного народа, после которой следуют его самостоятельные действия (обработка / осмысление) по освоению и адаптации того полезного «материала», который был воспринят извне [19, с. 178$]$.

Возвращаясь к рассуждениям Градовского о культурном заимствовании, следует уделить внимание сделанным им выводам о конструктивных способах этнокультурного взаимодействия. Во-первых, только те культурные приобретения прочны, которые «усваиваются обществом свободно, без принуждения». Иными словами, общество должно сделать вывод о необходимости заимствований, должно быть готово их понять и принять. Иначе в результате непонимания возникает конфликт социальных интересов, приводящций к внутригосударственным противоречиям, которые ослабляют государство. Далее, заимствование должно быть разумным, отличным от слепого подражательства, с адаптацией инноваций к своим собственным культурным элементам. И последенее, развитие народа должно быть последовательным («преемственным»), устойчивым [19, c. 205]. Таким образом, ситуация культурного отставания некой этнической группы является её собственной ответственностью. Также убедительно у Градовского звучит тезис о том, что нация, нацеленная на творчество, не может быть «порабощена» идеей экспансии, поскольку у неё есть более высокие цели: «Народ, привыкший к серьезной работе над собой, не будет стремиться к внешнему преобладанию; всеобщий труд вызовет действительное уважение одного народа к личности другого... Национальность и труд, национальность и творчество, национальность и школа, национальность и свобода - эти слова должны сделаться однозначащимися» [13, c. 158]. Под понятием творчества мыслитель, видимо, понимал материальную и духовную культуру нации и её позитивный вклад в мировую цивилизацию.

Через призму данных убеждений А. Д. Градовский, которому как человеку науки была интересна всякая концептуальность и враждебна воинственность инакомыслия, строит свои отношения со славянофильством. Он признаёт главную заслугу ранних славянофилов, которые протестовали против «заимствования самого содержания чужой национальной культуры, которой придано было значение 
культуры абсолютной...» $[19$, с. 179]. С этой точки зрения А. Градовский поддерживает И. Аксакова, который критиковал Петра I за то, что он «перенял от иностранщев не только полезное, но и национальное, саму жизнь иностранную..., он изменил на иностранный лад русский язык» [Там же]. Таким образом, идея, которую привнесли славянофилы, в конечном счёте состояла в том, что они выступили против «обезличения [собственного] народа», способствовали появлению самоуважения против самоуничижения. Проводя аналогию с Фихте, именно данное чувство самопризнания привело к подъему чувства единения немецкой нации.

С другой стороны, проявляя уважение к славянофилам и отдельным политикам, которые разделяли их взгляды, Градовский не разделял их отрицательного отношения к иным цивилизациям $[13$, с. 135$]$. Он убеждал, что «усвоение начал общечеловеческой цивилизации» не означает «отречения от своей народности» $[19$, с. 180$]$. Раннее славянофильство Градовский рассматривает как социальный протест. По Градовскому, он был направлен «против принесения в жертву национальных идеалов идеалам чуждых нам народов» (видимо, речь идёт и о социальном равноправии); против навязывания идеалов государством в принудительном порядке; против раздвоения земли и государства, против превращения государства в безличное абстрактное начало, а народа - в нравственно пассивную массу» [19, с. 173]. Для Хомякова и Аксакова в каждом народе важны его нравственные идеалы, нравственные идеи «коллективной личности» [Там же]. Данные взгляды славянофилов Градовский разделяет. Как было сказано ранее, он также всецело поддерживал представление о народе как о «собирательной личности». Понятие о национальном единстве, по Градовскому, «есть не что иное, как сознание своей собирательной личности, своего Я между другими народами», а поскольку «личность есть вещь святая», то и «посягательство на национальную личность есть величайшее из преступлений. Он решительно осуждает «метафизический космополитизм», «во имя которого доказывалось, что для человека все равно, к какому бы государству он ни принадлежал, что государство может быть составлено из каких угодно народностей и, наконец, что конечная цель человечества - составить всемирное государство» [Там же, с. 16-17].

Вместе с тем ученый убеждён, что европейские традиции и ориентиры приемлемы для России. И в этом он противостоит славя- нофилам. Градовский призывал отказаться от абсолютизации представления об уникальности русского народа: «Русский народ не есть совершенно особенный народ» [30, с. 416]. Рассматривая каждый народ как уникальную самобытную личность, ученый считал нелепым представление о «совершенно особенном народе, составляющем исключение из всех народов земного шара, народе, не подчиняющемся в развитии своём общим законам материального и нравственного мира. Народе, являющимся воплощенною утопиею» [30, c. 417]. Поэтому Градовский противостоит славянофилам, которые желают, «чтобы Россия не превратилась в Европу», поскольку для ученого «Россия есть Европа и русский народ есть народ европейский» [Там же]. Он также утверждает, что «русский народ, столкнувшись с европейской цивилизацией, не только не развратился и не погиб, но начал воспринимать эту цивилизацию как нечто своё...» [Там же]. Более того, Градовский утверждает, что в России «сознание... национальности просветлялось и укреплялось по мере проникновения в нашу среду европейской цивилизации» [30, с. 418]. Для ученого отказ от европейских ценностей («Возмущение против Европы») - это возмущение против самих себя: «Европа широко раскинулась перед нашими глазами; она доступна нашему изучению; она сама помогает нам в этом... Кто же, спрашивается, помешал бы нам взять из Европы то, что в ней есть всеобщего и существенно нужного... Прежде всего, невежество, из которого мы не вышли и по сей день. Невежда, будь это отдельный человек или целый народ, всегда схватывается только за внешнее и потому всегда начинает только с подражания внешнему... Во-вторых, если уж говорить о вреде заимствования и подражаний, то следует строго расследовать, что именно заимствовалось и чему подражалось... Может быть окажется, что мы никогда не заимствовали самого существа европейской культуры, ибо это существо не поработило бы нас Европе и не сделало бы из нас лакеев Запада, а напротив, содействовало бы нашему национальному самосознанию, а, следовательно, и освобождению от всяческого духовного рабства...» [26, с. 434 435]. В работе «Мечты и действительность» Градовский рассуждал о пользе культурных и социальных заимствований, которые полезны для России и позволят формировать сильное модерное государство [29, с. 382]. При этом необходимо отказаться от некоторых явлений, которые сформировались на российской почве, но являются камнем преткновения для государства. Среди 
них, например, «мерзость перед господом»пережитки крепостного права [29, с. 379].

Как следует из произведений Градовского, он ищет баланса, выступая также против представителей «воинствуюшего западничества», которые высказывают сомнения в способности русского народа к цивилизованности и европейским стандартам. При этом он замечает, что после Великих реформ «западничество как болезнь уменьшается с каждым годом, а национальное сознание в России растет с каждым десятилетием... Мы более национальны сейчас, чем в год франко-прусской войны» $[29$, с. 262$]$.

Россия и задачи национального строительства в работах Градовского.

Как горячий сторонник реформ Александра II ученый был убеждён, что Россия провела преобразования, сблизившие её с Европой и развившие её национальные силы [28, с. 316]. Градовский полагал, что уже в современную ему эпоху Россия стояла на рубеже того, чтобы стать величайшей страной Европы, в числе заслуг которой он называл подавление польского восстания 1863 г. Современное ему время Градовский именует периодом «начал равноправности, когда само слово «привилегия» Звучит неприятно...» [28, с. 286]. Последнее высказывание нуждается в коротком комментарии. Как известно, понятие империи и гомогенности являются несовместимыми, чего Градовский, видимо, до конца не осознавал. Выступая против привилегий (прежде всего, социальных), Градовский выступает как сторонник движения России в направлении к национальному государству, ядром которого должна стать некая народность / нация. При этом полностью нерешённым остаётся вопрос о том, по какой модели она должна была строиться. Единственным качеством нации, названным ученым, было равноправие составляющих её элементов.

Градовский полагает, что реформы Александра II устранили социальные ошибки, сделанные монархами, начиная с XVIII в. Его упрёки направлены в адрес Екатерины II, которая, по мнению учёного, нарушила традиционные социальные устои российского общества и ввела новые начала организации «состояний» (сословий), которые выражались в законном закреплении их неравноправия. Последнее, заметим, нашло выражение и в колонизационной политике: «Если вспомнить при этом, что законодательство, отрешённое от исторических обычаев народа, само было подчинено содержанию чужой жизни, принятой за образец, то нам будет понятен тот факт, что законодательство часто было ору- дием принудительного проведения в наш быт чужеродных начал» $[19$, с. 184]. Прежде всего, Градовский пишет, конечно же, о дворянстве, которое «принципиально противоположило себя остальной массе народонаселения, получившей тогда название «подлого народа»... Положение этого народа стало хуже...» $[19$, c. 186$]$. Однако данные рассуждения могли быть экстраполированы и на другие сословия (например, колонистов), которые, как полагали окружающие, получали свои привилегии несправедливо. При том, что у Градовского никогда не звучала критика и упоминание колонизации, неоднократно упоминаемой консерваторами, он тем не менее противопоставлял «западно-европейские майораты» (используемые в практике колонистского землевладения и в западных губерниях) государственным крестьянам, получившим «опеку» вместо самоуправления $[19$, с. 188]. В другой своей работе мыслитель упоминает внутренние факторы, препятствовавшие формированию народности в более ранний период: «Разрозненные сословия были неспособны к общему действу, они мало осознавали своё национальное единство» [28, с. 295].

Свою эпоху Градовский рассматривает как период формирования в России нового типа государства - «всесословно-общественного» $[28$, с. 294], когда происходит постепенное сближение сословий в их правах: «Смысл равноправности не только удовлетворяет чувству и сознанию правды... но и способствует развитию государственной силы»[Там же]. Он упоминает, что, например, «воинская повинность не только сделана всесословною, но и смягчена в своих формах сравнительно с прежнею рекрутчиной» [28, с. 295].

С другой стороны, сам процесс введения привилегий ученый рассматривает как важный прецедент предэмансипации общества. Привилегия, по Градовскому, проходит апробацию на избранном сословии, а затем (в исторической перспективе) распространяется и на другие: «Но были другие преимущества, в которых выразились лучшие общечеловеческие начала, в силу чего они не могли оставаться делом только одного сословия...» $[28$, с. 286$]$. Он иллюстрирует данный пассаж правом освобождения от телесной повинности, которое вначале распространялось на дворянство, а затем было расширено на мещанство: «Такова была роль этих привилегий; благодаря им, хотя на первый раз в узкой форме, в наше законодательство и в наше общество проникали понятия о законности, об уважении к правам, о невыгодах произвола» $[28$, c. 288]. И сам этот факт, как полагал Гра- 
довский, важен для воспитания нового поколения общества: «Под их влиянием выросли люди, сумевшие возвести частное к общему, отрешиться от узкосословного разделения... отвернуться от самих привилегий» [Там же].

Вспомним также, что важным условием образования народности (нации) Градовский считает наличие гражданских прав. Учёный показывает себя как убеждённый сторонник дальнейшей эмансипации общества: «Не может быть речи об условиях национального развития при отсутствии гражданской свободы массы народонаселения» [29, с. 365]. Свободное крестьянство и крепкая община (он в перспективе своего времени видит лишь такую форму низового самоуправления) - первое условие национального развития России. Самоуправление (здесь возможно и сословное представительство) должно строиться на всесословном принципе, ибо общественно активный человек «перестаёт быть гостем своей страны» [29, с. 369].

Градовский констатирует, что Россия отстаёт в процессах формирования народности. Суть проблемы для Градовского состоит не в особенностях имперской формы российской политии и сложности формирования нации, а в отсутствии гражданских прав и личных свобод: народ «держат на вожжах». Поддерживая реформы, ученый задаёт риторический вопрос западникам: «Во имя чего вы желаете всех этих вещей [то есть развития $-H$. B.] для народа, мало способного культуре и хорошего только до тех пор, пока его держат на вожжах? Ради чего хотите вы благодетельствовать разных Тишек, Прошек и Савосек, которых ваши же литераторы представляют в состоянии, близком к скотскому? Но от скотов разве может произойти что-нибудь кроме скотского?» [34, с. 270]. Его собственный ответ прост, и он состоит в следующем: народ следует наделить правами, и только на данной почве возможно консолидировать население России - сформировать народность (нацию).

Видится, что, конечно же, Градовский не был слепым идеалистом и патетиком в оценке реформ своего времени, но как исследователь социальных отношений он хотел увидеть будущее, увидеть модель, которая открывается перед Россией, предлагая оптимистический сценарий возможного формирования нации. Ранее российское государство основывалось на механическом соединении населения: «Такое государство ранее было внешним порядком, но не организмом, ибо понятие организма предполагает живое тело... Таким телом в области политики является народность (на- ция), с её физическими и нравственными особенностями, языком, историей, преданиями, правами, унаследованными стремлениями, со всем тем, что образует личность народную» $[28$, c. 298]. Однако в настоящее для ученого время «идея национальности сделала [в России] существенные успехи» [28, с. 299].

Тема национального языка является одной из сопутствующих для обсуждения в работах А. Д. Градовского. Под влиянием каких условий образуется чувство осознания естественной народности (племени) и народности? Поскольку явление народности не только историческое, но и культурное, ученый приходит к выводу, что именно «язык в большинстве случаев является главнейшим признаком народности... Он... становится таким признаком после долгой исторической работы... » $[15$, с. 261$]$. При этом у Градовского как ученого конечно же отсутствует политический подход к оценке проблемы. Его более интересует историческая генетика явлений. Градовский соглашается с Фихте, который подчеркивал, что немцы сохранили себя как самобытная нация именно потому, что они не изменили территорий своего происхождения и сохранили язык своих предков [13, с. 152]. Вслед за немецким мыслителем Градовский утверждал, что язык имеет мировоззренческое значение и «всегда выражает совокупность представлений, выработанных и пережитых народом...Только народ, говорящий своим языком, сознательно относится к этому органу духовной жизни и способен развить его согласно условиям своей природы» [13, c. 152-153]. В другой своей работе ученый утверждал, что «язык в такой степени связан с мыслью, что люди думают словами... Слово есть выражение пережитого представления народа о предметах и отношениях видимого и невидимого мира» $[15$, с. 260$]$.

Градовский предостерегал, что народ, лишённый своего языка, неизбежно замедляет своё развитие. Если народ вынужден учить чужой язык, «первоначально он становится в положение детей, обучаемых звукам, истинного смысла которых они не принимают... человеку нужно обращаться к прошлой истории другого народа, выработавшего соответствующие им представления... Духовная жизнь такого человека становится в зависимость от чужих представлений, сводится на простое подражание. Мёртвый язык - несостоятельность духовной жизни (народа), отсутствие творчества и самобытных идеалов» $[13$, с. 153]. Данные суждения являются иллюстрацией того, почему для ксенофобов и шовинистов языковая политика всегда слу- 
жила принципиальным фактором ассимиляции и способом ослабления конкурирующей этнической грушшы. Ответ на данный вопрос также присутствует у далёкого от политизации данной проблемы Градовского. Он обосновывает, что язык сохраняет активность нации и «только народ, говорящий своим языком, способен к прогрессу в умственной жизни» $[13$, с. $157-158]$.

Вместе с тем в условиях, когда публицисты, начиная со времён С. Уварова, обсуждали тему единого русского языка и национальной школы (как факторов консолидации российской нации), А. Градовский как ученый, стремившийся к объективности, упоминает кейз Швейцарии, пример которой демонстрирует, что при определённых условиях (присутствии гражданских прав и свобод) вполне возможно образование полиязычной народности $[15$, c. 261$]$.

Национальная идея и славянство. Рассуждая о генезисе и формировании национальных государств в Европе, Градовский указывает на своевременность обдумывания и провозглашения национальной идеи для самой Российской империи. Данная идея важна как инструмент осознанной консолидации подданных (или граждан) в составе нации: «Осознавая себя частью народности, каждая конкретная личность обретает содержание» $[15$, c. 259]. Позднее формирование российской нации (напоминаем, что конкретный механизм не упоминался) и осознание её идеи автор поясняет историческими обстоятельствами: «Вся вековая история наша есть не что иное, как упорная борьба за целостность нашей народности (борьба с монголами, собирание земель, деятельность Петра) [15, c. 258]. При этом, поднимая проблему национальной идеи, он настаивает на её четком определении и (важно!) секулярном содержании. Градовский выступал с критикой формулировки, предложенной В. С. Соловьевым («Задача России есть задача христианская, и русская политика должна быть христианскою политикою»), которую считал неконкретной, «темной и отвлеченной, способной подать повод к разным недоразумениям» [20, с. 451].

Историю формирования народности Градовский начинает со времён Екатерины II и донациональный период датирует правлением Николая I: «Во времена Екатерины II не только не было сознания национального начала, но самый национальный вопрос не возникал ни в жизни, ни в теории... Сами славяне не имели представления о своём единстве... Император Николай остался в кругу тех же идей» $[21$, с. 596]. Возникновение нацио- нального вопроса в России Градовский связывает не с польскими восстаниями, как это определяют современные исследователи, а рассматривает его как явление, возникшее под влиянием внешнего примера (европейских государств и их политики в XIX ст.): «Россия пережила эпоху возрождения Италии и объединения Германии. Национальный вопрос был услышан нами... из уст величайших государственных людей напего времени... Объединение Италии и Германии сделало возможным и необходимым провозглашение национального принципа и для мира славянского...» [21, с. 597].

Градовский также предлагает свой вариант национальной идеи для самой России. Как полагал ученый, она должна быть связана с проблемой славянства и укреплением позиций Российской империи в Европе («Русский народ стремится завоевать себе положение народа европейского» $[14$, с. 446]), тем более, что империи уже неоднократно удавалось проявлять свою значимость в континентальной политике. Так случилось, например, во времена наполеоновских войн, когда цели России были «штире и человечнее» $[15$, c. 255]. Именно Россия «разбудила» народы, дремавшие под гегемониею Наполеона, и теперь она может укрепить свой авторитет через идею славянского единства: «Славянский вопрос может быть разрешён только на основании национального начала, то есть того начала, которое дало жизнь Италии и Германии в наши дни» [21, с. 595]. Только Россия способна возглавить блок славянских держав (и тем прославить себя), и это соответствует её интересам : «...Европа относится к славянскому миру иначе, чем к любому западно-европейскому государству... Почему это так... Стоит только вдуматься в существо австрийских, английских и немецких интересов» $[21$, c. 598].

Градовский не столь часто теоретизирует над практическими рекомендациями для Российской империи. Его статья о Фихте и близкие к ней российские параллели наполнены настроениями поддержки идеи славянства, которые, видимо, противопоставляются кейзу объединения немецкой нации. При этом, в отличие от консерваторов и военных, у Градовского Германия упоминается не с целью запугивания. Градовского интересует фактический пример образования национального государства, едва ли не закономерный результат формирования нации, который могут повторить славянские государства. Противоставляя славянскую идею упоминаемой в публицистике угрозе немецкой экспансии, Гра- 
довский заверяет: «Нет, германское племя не сказало последнего слова цивилизации, владычество его падёт и будет отдано племени славянскому, в качествах которого таятся условия нового роста человеческой цивилизации» $[34$, с. 268$]$. Противопоставляя славянство и сопровождавшееся «огнём и мечем» объединение Германии, Градовский утверждает что, идея состоит не в том, чтобы разрушить Европу, а в том, чтобы «дать славянству свободу народности» $[34$, с. 270$]$.

Для реализации славянского единства важным является формирование единого мировоззрения: «Самосознание - вот великое слово, в котором нуждается наш славянский мир, рассеянный и рассыпанный подобно песку морскому!» [15, с. 263]. России следует проявить целеустремлённость и системность, поскольку «славянский вопрос [как любой национальный $-H . B$.$] не относится к числу таких,$ какие могут быть разрешены вдруг в полном объёме» [15, с. 227]. Как полагал мыслитель, «мало сочувствовать борьбе за национальную зависимость, нужно знать, что национальность как всемирно-историческое явление имеет глубокие основания в законах исторического развития человеческих обществ» $[15$, с. 225$]$. Идея славянства усиливает влияние России [11, с. 477] и, настаивает Градовский, «отстаивая славян, мы отстаиваем самих себя» [11, с. 478].

Ученый утверждает, что русский народ «имеет крепкое сознание своей национальности и умеет твёрдо и мужественно отстаивать свою самостоятельность...». Россиянам не следует бояться заимствований, которые не уничтожат русскость, а лишь создадут условия нового прогрессивного развития. Градовский напоминает, что жизнь каждого великого народа слагается из двух элементов - индивидуального и всеобщего. Индивидуальное - это осознание народом своих особенностей, что «необходимо для того, чтобы народ мог сохранить себя как личность». Всеобщее - это цивилизационная значимость народа, а вот «раскрытие всечеловеческого из собственного духовного содержания и усвоение всечеловеческого из других народов необходимо для того, чтобы народ мог играть всемирно-историческую роль» [26, с. 439]. Градовский утверждает, что лишь при гармоничном сочетании таких элементов возможна историческая жизнь. В этой связи учёный отвергает какую-либо «борьбу за чистую самобытность», что у Градовского звучит как отказ от социального прогресса, что не имеет ничего общего со здоровым национальным движением: «Успех же нынешнего «самобыт- ничества» есть актом отречения от всемирноисторической роли России» $[26$, с. 440$]$.

В контексте славянской теории особое внимание Градовскиий уделяет польскому вопросу. Характеризуя особенности появления проблемы и конфликта, он как историк возлагает ответственность на самих поляков, напоминая, что со времён разделов Польши отношение к представителям данной нации в Российской империи было исключительно благосклонным: «Пусть ответят на это поляки... как относилось к ним местное русское общество? Пусть скажут иноземцы, проживающие у нас, где встречали они больте уважения к своей народности? ...Нет народа, более способного уживаться со всеми народностями, более неспособного к национальной вражде, как именно русский народ. Перебирая в голове все воспоминания моего детства, все впечатления зрелого возраста, я не могу припомнить факта, в котором выразилась бы принципиальная и прирождённая ненависть русского к поляку!» [25, с. 616]. Вспоминая о правах поляков, ученый полагает, что Россия должна извлечь определённые уроки построения отнопений с инородцами (нетитульными этническими группами): «Излишняя доверчивость в политике неуместна и опасна. Мы все пережили события 1863 г. и живо помним, сколько бед натворила нам эта доверчивость. Не знаю только, что больше винить коварство ли поляков или наивность русских» $[23$, c. 619]. При этом Градовский оспаривал позицию Н. М. Костомарова (высказанную в статье «Письмо поляка-миротворца», «Новое время», № 478) о том, что коварство и обман национальная черта польского народа (цитирует пословишу, суть которой сам не поддерживает: «Жид всегда станет эксплуататором, а поляк - конспиратором») [23, с. 620]. Учёный убеждён, что при сохранении такого отношения к представителям двух упоминаемых этнических групп межэтнические противоречия никогда не будут решены и приведут к окончательному разрыву: «Еврейский и польский вопросы [будут]... решены так, как некогда вопрос еврейский был решён в Египте - исходом» [Там же].

Учёный осознаёт, что после второго польского восстания национальное чувство поляков находится в приниженном состоянии. Именно поэтому он считает важным защитить всех поляков от резких высказываний со стороны, например, М. Н. Каткова [27]. Он предлагает перевести конфликт в конструктивное русло, тем более что опыт двух польских восстаний и само основание конфликта оставляет возможность для его разрешения: 
«Если бы означенные меры были плодом национальной вражды и народного характера, то в них можно бы было видеть нечто роковое, неизбежное и непреходящее» [27, c. 616]. Однако в основе конфликта Градовский видит «вопрос о государственности», а посему в его разжигании заинтересованы лишь элиты.

Польский вопрос, как и славянский в целом, явился полем столкновения интересов западных держав и Российской империи. После восстания, продолжает ученый, российское общество воспринимает Польшу как «заговорщицу», «слоняюшуюся по всем западным дворам и проповедываюшую крестовый поход против России». Поляки, имевшие свой национальный проект, на западе искали защиты от России, и им «казалось, что все европейские престолы готовы по первому призыву явиться в Варшаву и защищать... Каждый либеральный французский публицист считал своею обязпанностью наговорить России множество неприятностей по поводу Польши» [27, с. 608]. Однако, заверяет ученый, «польский вопрос» был лишь орудием в руках франшузских дипломатов, направленном не в пользу Польши, но против России. Для Градовского совершенно очевидным являлся тот факт, что положение Польши не вызывало сочувствия у европейцев, которые не поддерживали восстановления государства в границах 1772 г., а посему «Польша должна осознать своё положение в славянском мире и, как часть этого мира, идти за одно с ним» $[22$, c. 604$]$. Это было самым верным и рациональным путём для польской нации, поскольку «государственный вопрос между Россиею и Польшей уже решён... Старой Речи Посполитой уже не будет и быть не может... Мы не отдадим Малороссии, нашего Киева, нашей Волыни, наших белорусов под ярмо господствующих классов Польши» [22, с. 605]. Градовский убеждён, что поляки должны остаться с Россией как славяне со славянской державой, сделать выбор между Россией и Германией, которая завершает свой национальный проект. Ученый убеждён, что «попав в реку германскую», поляки лишатся «того, из-за чего бьётся сердце ваше - народности. А этого блага никогда не отнимет у вас Россия» $[25$, с. 615]. Возвращаясь к национальной идее, Градовский также утверждает, что «гибель польской народности будет прямым ущербом для мира славянского, а для германского - приобретением» [25, с. 616]. А в письме к Костомарову он уточняет, что потеря Польши явится ударом для славянской идеи, а это может реально произойти, поскольку «ос- нование неславянского направления Польши есть её нелюбовь к России» [23, с. 625].

Градовскому также принадлежит важное наблюдение о том, что польское восстание являлось одним из тригтеров появления российского национального самосознания: «Припомните только настроение нашей интеллигенции в начале шестидесятых годов... Взрыв патриотизма, последовавший в 1863 г., был решительною неожиданностью для поляков и европейцев» $[23$, с. 624]. Проснулось то, что ученый поясняет следуюшим образом: «Я пишу не о самомнении народном - источнике застоя и всякого зла, а о самоуважении, без которого не мыслима ни частная, ни народная личность» $[23$, с. 625$]$.

Ученый ожидает объективно выгодного для обеих сторон примирения Польши и России. Репрессивные меры воспринимаются Градовским как контрпродуктивные: «Они не любезны нам самим. История всех стран учит, что необходимость исключительных мер в одной части государства всегда отражается на целом. Припомните, сколько вреда для нашего внутреннего развития причинили события 1863 г. Да и теперь многое и многое задерживается у нас ввиду наших «западных окраи»"» [25, с. 617].

В связи с польской проблемой Градовский находит возможность порассуждать о русском национальном характере: «Мы, русские, способны перемениться разом, круто повернуть фронт, возненавидеть недавних друзей и возлюбить вчерашних врагов. В этом наша сила и слабость. Поляки же слишком держатся своих преданий, чтобы от них можно было ожидать внезапных превращений. Но это не даёт нам права смотреть на нацию, как на величину, всегда себе равную, не поддающуюся новым историческим условиям. Напротив, здравая политика обязана зорко следить за изменением исторических комбинаций, принимать в расчет все новые явления и извлекать из них всевозможную выгоду для отечества» $[23$, c. 622$]$.

Религизный вопрос. Протестантизм В России. В контексте теоретического обсуждения вопросов о формировании российской нации консерваторами неоднократно поднимался и вопрос о роли религии как консолидирующего, так и дестабилизирующего фактора. Многие из теоретиков националистического дискурса поддерживали наработки славянофилов и, в частности, А. С. Хомякова, который называл религию «движущим началом истории». Поскольку религия лежит в основе цивилизационных противоречий, она является определяющим 
фактором мировоззренческих различий между Россией и Европой [2, с. 81].

Консерваторы более всего остерегались влияния неправославных западных религий (протестантизма, католичества, лютеранства) на население империи, которые, как считал, например, К. Победоносцев, способствовали моральному, а затем и территориальному порабощению государства, определяя национальное конфессиональным [9]. В вопросах религии Градовский вновь выступает как ученый, и его рассуждения носят скорее общетеоретический характер. Однако и в его анализе находится множество «полезныху рассуждений, способных либо усилить, либо ослабить позиции тех, кто принимает участие в дискуссиях о проекте российской нации. В работе «Национальный вопрос» он, например, пишет o способности религий действовать извне, сковывая процессы внутреннего нациетворчества: «Католичество, как унифицированная система подчинения власти папства, сковывало развитие народностей $[15$, с. 244$] »$, «правоверный католик-француз осознавал своё единство с католиком-немцем или итальянцем, но француз-еретик был для него чем-то отверженным и презренным» [Там же]. Приведём ещё одно наблюдение учёного о влиянии католицизма: «Нужно ли говорить о клериках во Франции, для которых свобода и честь родной страны ничто в сравнении с интересами римской курии?» $[15$, с. 245]. Или же, например, по Градовскому, протестанты всех стран объединены верой! Таким образом, весьма пугающе звучит вывод о том, что религиозное единство во времена средневековья было наимощнейшим средством надгосударственного влияния.

Из всех «западныгх" религий, сохранявших влияние в России, Градовский особенно выделял католицизм: «Даже и теперь, если бывают случаи отпадения от православия, то отпадающий бросается в католицизм, но я не знаю случая перехода в протестантизм» [19, c. 216]. Описывая историческую роль протестантизма, популярность которого в Российской империи стала источником страхов в последней четверти XIX ст., Градовский отмечает большую толерантность адептов религий периода Реформации, что исходит из исторической генетики его происхождения: «Протестантские церкви во многих отношениях столь же мало были воодушевлены терпимостью к другим вероисповеданиям, как и католицизм, но их нетерпимость никогда не доходила до таких результатов, и притом она смягчалась с каждым поколением. Различие религий не являлось уже помехой наци- ональному единству. В протестантских землях немец-католик мог быть таким же добрым гражданином своей страны как и немец-протестант» [15, с. 249]. И далее автор уточняет: «Если протестантское начало содействовало развитию религиозной свободы внутри каждой страны, если различие вероисповеданий не препятствовало единению всех членов одной народности, то в деле различий между целыми народами протестантское движение было шагом вперёд» [Там же].

В особенностях личности-протестанта (в отличие, например, от взглядов, высказанных Победоносцевым десятилетие спустя) он видит полезные черты: «Начало индивидуальности, личной самостоятельности, таившееся в мире германском, прорвалось наружу, выразилось в формах церковной жизни... » [15, c. 249]. Какие это качества? Как следует из текстов Градовского, это осознание чувства собственного достоинства, стремление к этническому единению, которые явились «накоплением материала, из которого образовались народности».

Градовский также упоминает о значении пиетизма как одной из форм протестантизма, о деятельности Российского библейского общества [6], которому активно противостояло русское православие в лице архимандрита Фотия и его сторонников [6, с. 359]. В российском обществе с особой осторожностью относились к иноконфессиональному миссионерству. Речь шла о деятельности общества, которое функционировало после 1812 г. в Петербурге. Организацию возглавлял видный сановник А. Н. Голицын, а собрание однажды посетил министр народного просвещения и автор знаменитой «триады» С. Уваров. В 1813 г. организация издала Библию на немецком и финском, Новый Завет - на калмыцком и армянском языках. К началу 1823 г. было организовано издание Библии на 41 языке. Хотя Общество «обслуживало» как иностранных подданных империи, так и православных, далеко не все разделяли дух экуменизма. Разрушение общества в середине 1820-х свидетельствовало о замирании религиозного просветительства при Николае I, для которого православие становилось средством укрепления связи «самодержавия» и «народности» [46].

В отличие от «столпов православия», Градовский являлся сторонником свободы совести, которую он считал одним из важных гражданских прав. Приветствуя либеральный дух, учёный верил в реформирование государства, и, например, полагал, что, занимаясь вопросами о раскольниках, «правительство... 
несомненно прийдёт к вопросу о свободе совести вообще» (об этом, например, писал Ю. Ф. Самарин), что и будет пагом к настоящему гражданскому воспитанию [18, с. 411$]$.

Вместе с тем ученый не снимает вопрос о том, какими путями в условиях органичной для России поликонфессиональности было возможным удержать народ в рамках православия, которое, по Градовскому-историку, «есть коренной чертой русской народности» $[29$, с. 387$]$. Для ученого религия важна как духовный источник, способный наполнить нацию. Градовский признаёт, что русский народ, который создал огромное государство, до сих пор скорее боролся за существование, чем «наполнил государственное тело духовным содержанием» [Там же], а его религия более «превратилась в обрядность». А посему, хотя «свобода совести есть первейшее условие духовной жизни в народе..., эта азбука остаётся недосягаемым идеалом [для России]» [29, c. 392].

Россия и Германия: германский национализм и перспективы возможного конфликта. Отношение с Европой и ведущими государствами - один из ключевых элементов в дискуссиях российского националистического дискурса. В середине XIX ст. в Европе произошло формирование новой системы отношений между континентальными империями. В России, как и в других государствах Европы, с интересом и опасением наблюдали за возникновением и развитием объединённой Германии, процессами формирования единой нации с тенденщией превращения государства в империю. Эта проблема активно дискутировалась в обоих лагерях российского политического истеблишмента, и Градовский как теоретик не мог оставить её без внимания. Будучи представителем государственной школы, он идеализировал Германию как молодое национализирующееся государство, и в его рассуждениях в целом отсутствовало ожидание будущего глобального конфликта. Боязнь германской экспансии Градовский поясняет тем, что процессы формирования новой политии явились неожиданностью для Российской империи: «Германия долго готовилась к неизвестному ещё, но великому будущему. Мы проглядели эту работу. Убаюканные ловкостью Меттерниха, мы спокойно смотрели на Германию как на отечество невинного идеализма и романтизма, и не полагали, что это были симптомы сильного национального движения, прорвавшегося, наконец, в 1848 г...» [28, с. 292]. Россия долго проявляла нейтралитет, и до Крымской войны, когда вся Европа видела в империи сильную воен- ную державу, «все реакционные стремления немцев находили себе опору в России» [11, c. 457]. Отмечая кровную связь между российской и немецкой монаршими династиями, Градовский находит исторические корни, которые обусловили политические противоречия и точки притяжения в отношениях между Россией и Германией. Во-первых, Россия в 1848 г. поддержала Австрию (в дальнейшем исключенную из младогерманского проекта) с целью обеспечить дипломатическое поражение Пруссии, добившейся права стать политическим ядром объединения. В этом ведущую роль сыграл «варцинский отшельник» О. Бисмарк: «ОН, вождь цивилизованной нации, держит в своих руках мир и войну. Его сотрудники возвели военное искусство в степень науки...». Тогда Россия не только не останавливала, но и поддерживала развитие германского единства, и дважды её «дружественный нейтралитет» $(1866,1870$ гт.) оказал неоценимые и неоценённые услуги Германии $[11$, с. 460$]$.

Как было сказано выше, современные для Градовского российско-германские проблемы основывались на противостоянии двух национальных идей - германизма (пангерманизма) и славянского вопроса (включая польский) как двух глобальных европейских геополитических кластеров: «Наши отношения с Германией также связаны интересами германской народности, с одной, и положением России как славянской державы, с другой». Он полагает, что на Берлинском конгрессе Бисмарк предал огласке дипломатические цели, которые состояли в завершении проекта объединения [28, с. 300]. Однако Градовский полагает, что, вопреки опасениям многих, национальные задачи новой империи не представляют угрозу для решения славянского вопроса: «Германская империя не имеет прямых интересов на Балканском полуострове. Есть основание думать, что если восточный вопрос начнёт разрешаться, она приступит к разрешению других вопросов, не балканских, а более близких» $[11$, с. 463$]$. И в другой публикации учёный писал об исторической близости двух политий: «Интересы народов вырабатываются их вековой историей... В этом смысле интересы Германии и России не расходились по всем капитальнейшим вопросам новейшей истории. Издавна подготовлявшееся соединение России и Прусиии, ставшей во главе Германии, было закреплено в великую эпоху 1813 г. Оно развивалось при императорах Николае I и Александре II, недвусмысленно доказавшем своё расположение к Германии. Наш дружественный нейтралитет 
1870 г. был именно результатом этого соединения интересов. Во имя этих же интересов... мы и теперь в праве ожидать благоприятного для нас поведения Германии» [24, с. 504 505]. Вопроса о «внутреннем германизме» в России Градовский фактически не поднимал.

Не оставляя нейтральный тон и в более поздней статье («Полемики с немецкой печатью») о якобы враждебной России германской прессе, учёный в ответ на современную ему полемику признаёт, что «в Германии есть элементы, враждебные России; каждый знает, что существуют и газеты, являющиеся органами этих элементов» и разжигающие межгосударственную рознь $[24$, с. 501$]$. Однако Градовский убеждён, что далеко не каждая немецкая газета, выступающая с антироссийской риторикой, отражает интересы немецкого народа и влияет на политику: «История образования нынешней Германской империи... сложилась не по плану газет и парламентских партий» [Там же]. Как полагает Градовский, существует взаимное предубеждение как внутри России против Германии, так и в Германии против России. Однако его не следует рассматривать как предубеждение властей. Это, по мнению учёного, отражает искусственно раздутые страхи оппозиции, которая использует настроение отдельных групп для раздувания критики своего правительства $[24$, c. 504$]$.

Комментируя современную политику Германии, Градовский не демонстрирует присутствие дара исторического предвидения. Он был убеждён, что молодое национализирующееся государство «не имеет никакого основания желать, чтобы законная доля влияния России на Восток была уничтожена», а Англия самостоятельно распоряжалась на Балканах. Он надеется на поддержку со стороны Германии в случае войны России с Турцией: «...Есть основание полагать, что имперское правительство даст нам то, что мы дали ему в 1870 г.» [24, с. 505]. Поэтому все опасения относительно германской угрозы ученый считает неосновательными: «Мы знаем Германию лучше, чем кёльнские публицисты знают Россию. Мы знаем, что в Германии достойно уважения, и умеем уважать это» $[24$, с. 506]. Его заключения звучат упрёком не только немецким, но и российским публицистам. Поскольку «германизм не противен славянству настолько, насколько желали бы этого некоторые публицисты» [Там же], проявляемая немцами русофобия, как заключает Градовский, разжигается и русской стороной: «Те же публицисты пользуются каждым словом наших газет для доказательства ненависти, развившейся вроде бы в русском обществе к Германии, ненависти, которой нет и быть не может» [Там же].

Выводы: а был ли проект? А. Д. Градовский предстал перед российским обществом в двух ипостасях: как интеллектуал - транслятор европейских идей, и как теоретик, самостоятельно продуцирующий знания. Являясь скорее учёным и наблюдателем, чем политиком и публицистом, Градовский выполнил роль репрезентанта важного для европейской геополитики XIX в. явления формирования национальных государств, рефлексируя данный опыт через призму истории Российской империи и актуализируя его в связи с важностью вопроса для своего государства. Его позитивная европоцентричность особенно важна в связи с тем, что доминирующая идеология в России долгое время преимущественно отторгала западный путь развития.

Большинство работ Градовского по национальной проблематике были созданы в переломные для концептуального осмысления национализма 1870-е гт. Следует признать, что ученый так и не сумел (или же не пожелал) предложить глобальный национальный проект для Российской империи, как, впрочем, не сделали это и другие либералы, которые либо перешли в лагерь консерваторов, либо, самоустранившись (как это сделал ученый после 1881 г.), передали тему нациестроительства на откуп своим оппонентам. Роль Градовского состоит, прежде всего, в обсуждении, презентации европейского опыта, его (одной из первых) научной обработке и осмыслении. Проецируя европейские явления на российский социальный контекст, учёный обращает внимание на наиболее болезненные моменты состояния общества, которые препятствуют продвижению государства по пути формирования национального проекта и требуют реформирования. Считая создание национальных государств главной тенденцией эпохи, Градовский в своих исследованиях предоставляет своим ученикам и российскому читателю некоторую теоретическую информацию для понимания европейских процессов, которую идеологи национализма (по иронии судьбы, представители противоположных позиций) в дальнейшем могли использовать при составлении и аргументации своих, опять же, конкурирующих проектов.

В контексте теоретических рассуждений автор создал собственную концепцию этноса (племени, естественной народности) и нации (народности), поднимал вопрос о роли языка и государственной языковой унификации, высказывался по вопросам о функциональ- 
ной роли религии титульной группы, выступал за свободу совести. Темы личных свобод, ликвидации сословий, эмансипации крестьнства имели для учёного важнейшее значение и во многом были аргументированы задачами строительства нации. Градовский коснулся и проблемы выбора национальной идеи, которую он связывал со славянством, но, как нам видится, не пропагандировал идею панславизма. Поддерживая решительные действия в подавлении польского восстания, учёный настаивает на необходимости продолжения диалога с поляками. При решении немецкого вопроса он требовал отказа, прежде всего, от внутренней российской ксенофобии, подозрительности в отношении Германии. Последняя апологетическая позиция и оптимистическое восприятие молодого национализирующегося государства не прошли верификацию в ближайшей исторической перспективе.

Несмотря на то, что для Градовского национальное государство - наиболее прогрессивный тип политии, в рамках которого «может разрешиться множество противоречий», автор не до конца осознал, что исторические обстоятельства развития России как континентальной империи могут ограничить пространство выбора. В работах автора не прослеживалась его позиция о том, как из Российской империи (со всей её гетерогенностью и множеством противоречий) возможно было создать его собственный идеал - национальное государство, сформировав при этом консолидированную нацию. Тема включения / исключения племенных компонентов им фактически не обрабатывалась. Недостаточно ясным является то, каковым должен быть состав нации. Автор лишь упоминал о том, что набор этнических компонентов мог меняться. Отсутствие такого обсуждения может означать, что в его понимании нация должна иметь общий (всероссийский) характер. При этом следует подчеркнуть, что определение нации, по Градовскому, строится скорее через призму включения и объединения исторически сродных этнических групп (нация надэтническая структура). Градовский лишь отчасти (скорее теоретически) касался прикладной проблемы межэтнического взаимодействия внутри огромной полиэтнической политии. Учёный провозглашал необходимость свободного развития этносов (не исключая их органичной ассимиляции) как способа социальной эмансипации, по которому, как он был убеждён, Россия продвигалась с начала Великих реформ.

В тематике и содержании разработок А. Д. Градовского отразилась переходная эпоха истории России, стремительно идущая к новому веку и его политическим инновациям. Поднимая на новую высоту национальную проблематику (в широком спектре данного понятия) учёный стремился сделать Россию равным партнёром клуба европейских государств, привнести теоретическую основу в политический дискурс своего времени. Его рассуждения свидетельствовали о начальном этапе осмысления явления, демонстрируя при этом научное родство и сущностные противоречия между российской и западной цивилизациями.

\section{Библиографические ссылки}

1. А.Д. Градовский. Глинский Б. Б. Очерки русского прогресса: Статьи исторические, по общественным вопросам и критико-биографические. СПб., 1900. C. $538-550$.

2. Бердяев Н. А. Русская идея. Основные проблемы русской мысли XIX века и начала XX века. О России и русской философской культуре. М., 1980. С. 43-272.

3. Библиографический указатель трудов А. Д. Градовского. Журнал Министерства юстиции. 1897. № 3. C. $391-409$.

4. Бочкарёв В. Юрий Фёдорович Самарин. Великая реформа. Русское общество и крестьянский вопрос в прошлом и настоящем: в 5 ч. М., 1911. Ч. 5. С. 92-107.

5. Брояко Ю. В. Политико-правовые воззрения А. Д. Градовского: автореф. дис. канд. юр. наук. Саратов, 2006. 221c.

6. Великанов Г. В. Российское Библейское общество как явление духовной жизни. Государство, религия, церковь в России и за рубежом. 2006. № 1-2.

7. Венгер Н. В. «Німецьке питання» в оцінці I. С. Аксакова та Ю. Ф. Самаріна: діалог з російським суспільством у десятиліття Великих реформ (18601870). Вопросы германской истории. Д., 2011. С. 30-52.

8. Венгер Н. В. Проблеми реформування іноземних колоній та ідея єдності російської нації М. Н. Каткова: біля витоків російського націоналістичного дискурсу. Вопросы германской истории. Д., 2010. С. 30-50.

9. Венгер Н. В. Психология и метаморфозы русского национализма в деятельности К. П. Победоносцева. Вопросы германской истории: сб. научн. тр. Д., 2013. C. $61-91$.

10. Голос. Русская периодическая печать (17021894): Справочник. М., 1959. С. $436-437$.

11. Градовский А. Д. Внешняя политика России в 1875 г. Собрание сочинений А. Д. Градовского: в 9 т. СПб., 1900. Т. 6. С. 457-465.

12. Градовский А. Д. Внутреннее противоречие Берлинского конгресса. Собрание сочинений А. Д. Градовского: в 9 т. СПб., 1900. Т. 6. С. 587-590.

13. Градовский А. Д. Возрождение Германии и Фихте Старший. Собрание сочинений А. Д. Градовского: в 9 т. СПб., 1900. Т. 6. С. 107-159. 
14. Градовский А. Д. Мечтания самобытника. Собрание сочинений А. Д. Градовского: в 9 т. СПб., 1900. T. 6. C. 441-447.

15. Градовский А. Д. Национальный вопрос. Собрание сочинений А. Д. Градовского: в 9 т. -СПб., 1900. T. 6. C. 225-263.

16. Градовский А. Д. Национальный вопрос в истории и в литературе. СПб., $1873.372 \mathrm{c}$.

17. Градовский А. Д. Национальный вопрос в истории и литературе. Собрание сочинений А. Д. Градовского: в 9 т. СПб., 1900. Т. 6. С. 3-224.

18. Градовский А. Д. Не архитектуры, а жизни. Собрание сочинений А. Д. Градовского: в 9 т. СПб., 1900. T. 6. C. 401-411.

19. Градовский А. Д. Первые славянофилы. Собрание сочинений А. Д. Градовского: в 9 т. СПб., 1900. T. 6. C. 160-224.

20. Градовский А. Д. Пессимист. Собрание сочинений А. Д. Градовского: в 9 т. СПб., 1900. Т. 6. C. $447-454$.

21. Градовский А. Д. Письмо к Высокопреосвященному Михаилу, Прхиепискому Белградскому, Митрополиту Сербскому. Собрание сонинений А. Д. Градовского: в 9 т. СПб., 1900. Т. 6. С. 594-599.

22. Градовский А. Д. Письмо к И. С. П. по поводу польского вопроса. Собрание сочинений А. Д. Градовского: в 9 т. СПб., 1900. Т. 6. C. 603-605.

23. Градовский А. Д Письмо к Н. И. Костомарову. Собрание сочинений А. Д. Градовского: в 9 т. СПб., 1900. T. 6. C. 619-626.

24. Градовский А. Д. Полемики с немецкой печатью. Собрание сочинений А. Д. Градовского: в 9 т. СПб., 1900. Т. 6. С. 501-506.

25. Градовский А. Д. Польский вопрос (ответ на письмо эмигранта). Собрание сочинений А. Д. Градовского: в 9 т. СПб., 1900. Т. 6. С. 613-618.

26. Градовский А. Д. По поводу одного предисловия (Н. Страхов. Борьба с Западом в нашей литературе. СПб., 1882). Собрание сочинений А. Д. Градовского: в 9 т. СПб., 1900. T. 6. C. 424-440.

27. Градовский А. Д. По поводу польского легиона в Турции. Собрание сочинений А. Д. Градовского: в 9 т. СПб., 1900. Т. 6. С. 606-612.

28. Градовский А. Д. Прошедшее и настоящее. Собрание сочинений А. Д. Градовского: в 9 т. СПб., 1900. T. 6. C 273-308.
29. Градовский А. Д. Реформы и народность. Собрание сочинений А. Д. Градовского: в 9 т. СПб., 1900. T. 6. C. 353-374.

30. Градовский А. Д. Славянофильская теория государства. Собрание сочинений А. Д. Градовского: в 9 т. СПб., 1900. Т. 6. С. 412-423.

31. Градовский А. Д. Собрание сочинений А. Д. Градовского: в 9 т. СПб., 1899-1908.

32. Градовский А. Д. Собрание сочинений А. Д. Градовского: в 9 т. СПБ., 1901. Т. 6. 635 с.

33. Градовский А. Д. Современные воззрения на государство и национальность. Собрание сочинений А. Д. Градовского: в 9 т. СПб., 1900. Т. 6. С. 28-106.

34. Градовский А. Д. Старое и новое славянофильство. Собрание сочинений А. Д. Градовского: в 9 т. СПб., 1900. Т. 6. С. 464-472.

35. Градовский А. Д. Сочинения. СПб., 2001. С. 460.

36. Гросул В. Я., Итенберг Г. С., Твардовская В. А., Шацилло К. Ф., Эймонтов Р. Г. Русский консерватизм XIX стол. Идеология и практика. М., 2000. 440 с.

37. Гуляк И. И. Социально-политическая философия А. Д. Градовского: дис. док-ра филос.наук. СПб, 2001.

38. Замалеев А. Ф. А. Д. Градовский. Веде. 1999. Вып. 12. С. 76-86.

39. Ивановский И. А. А. Д. Градовский как ученый. СПб, 1900. 13 с.

40. Ильин Н. К 175 летию А. Градовского [Электронный pecypc]. URL: http://koksheneva.ru/posts/ gradovskiy/

41. Миллер А. История понятия «нация» в России. Понятие о России: к исторической семантике имперского периода. М., 2012. С.7-49.

42. Плященко Т.Е. Политические и исторические взгляды А. Д. Градовского: автореф. на соиск. степ. канд. истор. наук. Воронеж, 2004.

43. Свешников М. Градовский (Александр Дмитриевич). Энциклопедический словарь Брокгауза и Ефрона: в 86 т. СПб., 1892. Т. 9 а. С. 491-492.

44. Сементковский Р. Михаил Катков. Его жизнь и литературная деятельность. СПб., 1892.90 с.

45. Струве П. Б. Апокалипсис против истории. Патриотика: Россия. Родина. Чужбина. СПб., 2000. 352 с.

46. Фирсов С.Л. Религиозная политика и народное благочестие в России (1825-1861). Церковь и время. Научно-богословский и церковно-общественный журнал. 2005. № 1 (30). С. 200-204.

47. Фойницкий И.Я., Коркунов Н.М., Кони А.Ф. Памяти А.Д. Градовского. СПб., 1890. 47c.

\section{References}

1. A. D. Gradovskij. Glinskij B. B. Ocherki russkogo progressa: Stat'i istoricheskie, po obshchestvennym voprosam $i$ kritiko-biograficheskie [Essays on Russian Progress: Historical Articles, on Social Issues and Critical Biographical ]. SPb, 1900. S. 538-550 (in Russian).

2. Berdyaev N. A. Russkaya ideya. Osnovnye problemy russkoj mysli XIX veka i nachala XX veka. O Rossii i russkoj filosofskoj kul'ture [Russian idea. The main problems of Russian thoughts of the XIX-th century and the beginning of the XX-th century. About Russia and Russian philosophical culture]. M., 1980. S. 43-272 (in Russian).

3. Bibliograficheskij ukazatel' trudov A.D.Gradovskogo. Zhurnal Ministerstva Yusticii. [Bibliographic index of A.D. Gradovsky's works. Journal of the Ministry of Justice].1897. № 3. S. 391-409 (in Russian).
4. Bochkaryov V. Yurij Fyodorovich Samarin. Velikaya reforma. Russkoe obshchestvo i krest'yanskij vopros v proshlom i nastoyashchem: in 5 vol. [Yuri Fedorovich Samarin. Great Reform. Russian society and the peasant question in the past and present: in 5 vol.]. M., 1911. Vol. 5. S. 92-107 (in Russian).

5. Broyako YU.V. Politiko-pravovye vozzreniya A. D. Gradovskogo [Political and legal views of A.D. Gradovsky]: avtoreferat kand.yurid.nauk. Saratov, 2006. 21 s. (in Russian).

6. Velikanov G. V. Rossijskoe Biblejskoe obshchestvo kak yavlenie duhovnoj zhizni. Gosudarstvo, religiya, cer-

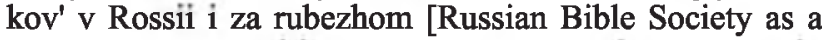
Phenomenon of Spiritual Life. State, Religion, Church in Russia and Abroad]. 2006. № 1-2 (in Russian). 
7. Venger N. V. «Nimecz'ke py`tannya» v ocinci I. S. Aksakova ta Yu. F. Samarina: dialog $z$ rosijs'ky'm suspil'stvom u desyaty'littya Vely'ky'x reform (18601870). Voprosi germanskoj y'story'y' ["German Issue" in assessment of S. Aksakov and Y. F. Samarin: dialogue with the Russian suspension in the ten years of the Great Reforms (1860-1870). Questions of German history]. Dnepropetrovsk, 2011. S. 30-52 (in Russian).

8. Venger N. V. Problemy' reformuvannya inozemny'x kolonij ta ideya yednosti rosijs 'koyi naciyi M. N. Katkova: bilya vy"tokiv rosijs 'kogo nacionalisty'chnogo dy'skursu. Voprosi germanskoj y'story'y' [Problems of foreign colonies reforming and the idea of the united Russian nation by M. N. Katkov: the turn of the Russian national discourse Questions of German history]. Dnepropetrovsk, 2010. S. 30-50 (in Russian).

9. Venger N. V. Psihologiya i metamorfozy russkogo nacionalizma v deyatel'nosti K. P. Pobedonosceva. Voprosy germanskoj istorii [Psychology and metamorphoses of Russian nationalism in the activities of K. P. Pobedonostsev. Questions of German history]. Dnepropetrovsk, 2013. S. 61-91 (in Russian).

10. Golos. Russkaya periodicheskaya pechat' (17021894): Spravochnik [Voice. Russian Periodicals: Guide book]. M., 1959. S. 436- 437 (in Russian).

11. Gradovskij A. D. Vneshnyaya politika Rossii v 1875 g. Sobranie sochinenij A. D. Gradovskogo: v 9 vol. [Foreign policy of Russia in 1875 . Collected works by A.D. Gradovsky: in 9 vol.]. SPb, 1900. Vol. 6. S. 457-465 (in Russian).

12. Gradovskij A. D. Vnutrennee protivorechie Berlinskogo kongressa. Sobranie sochinenij A. D. Gradovskogo: v 9 vol. [Internal contradiction of the Berlin Congress. Collected Works by A. D. Gradovsky: in 9 vol.]. $\mathrm{SPb}, 1900$. Vol. 6. S. 587-590 (in Russian).

13. 13.Gradovskij A. D. Vozrozhdenie Germanii i Fihte Starshij. Sobranie sochinenij A. D. Gradovskogo: in 9 vol. [Revival of Germany and Fichte the Elder. Collected Works by A.D. Gradovsky: in 9 vol.]. SPb, 1900. T. 6. S. 107-159 (in Russian).

14. Gradovskij A. D. Mechtaniya samobytnika. Sobramie sochinenij A. D. Gradovskogo: in 9 vol. [Dreams of the original. Collected works by A.D. Gradovsky: in 9 vol.]. SPb, 1900. Vol. 6. S. 441-447 (in Russian).

15. Gradovskij A. D. Nacional'nyj vopros. Sobranie sochinenij A. D. Gradovskogo: in 9 vol. [National issue]. $\mathrm{SPb}, 1900$. Vol. 6. S. 225-263 (in Russian).

16. 16. Gradovskij A. D. Nacional'nyj vopros v istorii $\mathrm{i}$ literature [National issue in history and literature]. Spb, 1873. 372 s. (m Russian).

17. Gradovskij A. D. Nacional'nyj vopros v istorii i literature [National issue in history and literature]. Sobranie sochinenij by A. D. Gradovskiy: in 9 vol. SPb, 1900. Vol. 6. S. 3-224 (in Russian).

18. Gradovskij A. D. Ne arhitektury, a zhizni. Sobramie sochinenij A. D. Gradovskogo: in 9 vol. [Not architecture, but life. Collected works by A. D. Gradovsky: in 9 vol.]. SPb, 1900. Vol. 6. S. 401-411 (in Russian).

19. Gradovskij A. D. Pervye slavyanofily [The first slavianofils]. Sobranie sochinenij by A. D. Gradovsky: in 9 vol. SPb, 1900. Vol. 6. S. 160-224 (in Russian).

20. Gradovskij A. D. Pessimist. Sobranie sochinenij A. D. Gradovsky: in 9 vol. [Pessimist. Collected works by A.D. Gradovsky: in 9 vol.]. SPb, 1900. Vol. 6. S. 447-454 (in Russian).

21. Gradovskij A. D. Pis'mo k Vysokopreosvyashchennomu Mihailu, Prhiepiskomu Belgradskoinu, Mitro- politu Serbskomu. Sobranie sochinenij A. D. Gradovskogo: v 9 vol. [Letter to His Eminence Michael, Archbishop of Belgrade, Metropolitan of Serbia. Collected Works by A.D. Gradovsky: in 9 vol.]. SPb, 1900. Vol. 6. S. 594-599 (in Russian).

22. Gradovskij A. D. Pis'mo k I. S. P. po povodu pol'skogo voprosa. Sobranie sochinenij A. D. Gradovskogo: in 9 vol. [Letter to I.S.P. about the Polish question. Collected works of A.D. Gradovsky: in 9 vol.]. SPb, 1900. Vol. 6. S. 603-605 (in Russian).

23. Gradovskij A. D Pis'mo k N. I. Kostomarovu. Sobranie sochinenij A. D. Gradovskogo: v 9 vol. [Letter to Kostomarov. Collected works by A.D. Gradovsky: in 9 vol.]. SPb, 1900. Vol. 6. S. 619-626 (in Russian).

24. .Gradovskij A. D. Polemiki s nemeckoj pechat'yu. Sobranie sochinenij A. D. Gradovskogo: in 9 vol. [Discussion with German periodicals. Collected works by A.D. Gradovsky: in 9 vol.]. SPb, 1900. Vol. 6. S. 501 (in Russian).

25. Gradovskij A. D. Pol'skij vopros (otvet na pis'mo emigranta). Sobranie sochinenij A. D. Gradovskogo: in 9 vol. [Polish issue (the answer to emigrant's letter). Collected works by A.D. Gradovsky: in 9 vol.]. SPb, 1900. Vol. 6. S. 613-618 (in Russian).

26. Gradovskij A. D. Po povodu odnogo predisloviya (N. Strahov. Bor'ba s Zapadom v nashej literature. SPb, 1882). Sobranie sochinenij A. D. Gradovskogo: v 9 vol. [Regarding the Introduction. Collected works by A.D. Gradovsky: in 9 vol.]. SPb, 1900. Vol. 6. S. 424-440 (in Russian).

27. Gradovskij A. D. Po povodu pol'skogo legiona v Turcii. Sobranie sochinenij A. D. Gradovskogo: v 9 vol. [Concerning the Polish Legion in Turkey. Collected Works by A.D. Gradovsky: in 9 vol.]. SPb, 1900. Vol. 6. S. 606612 (in Russian).

28. Gradovskij A. D. Proshedshee i nastoyashchee. Sobranie sochinenij A. D. Gradovskogo: in 9 vol. [Past and Present. Collected Works by A. D. Gradovsky: in 9 vol.]. $\mathrm{SPb}, 1900$. Vol. 6. S 273-308 (in Russian).

29. Gradovskij A. D. Reformy i narodnost'. Sobranie sochinenij A. D. Gradovskogo: in 9 vol. [Reforms and Nationality. Collected works by A. D. Gradovsky: in 9 vol.]. $\mathrm{SPb}, 1900$. Vol. 6. S. 353-374 (in Russian).

30. Gradovskij A. D. Slavyanofil'skaya teoriya gosudarstva. Sobranie sochinenij A. D. Gradovskogo: in 9 vol. [The Slavophils' theory of the state. Collected works by A. D. Gradovsky: in 9 vol.]. SPb, 1900. Vol. 6. S. 412423 (in Russian).

31. Gradovskij A. D. Sobranie sochinenij A. D. Gradovskogo : in 9 vol. [Collected works by A.D. Gradovsky: in 9 vol.]. SPb., 1899-1908 (in Russian).

32. Gradovskij A. D. Sobranie sochinenij A. D. Gradovskogo: in 9 vol. [Collected works by A.D. Gradovsky: in 9 vol.]. SPb., 1901. Vol. 6. 635 s. (in Russian).

33. Gradovskij A. D. Sovremennye vozzreniya na gosudarstvo i nacional'nost'. Sobranie sochinenij A. D. Gradovskogo: in 9 vol. [Modern views on the state and nationality. Collected works by A. D. Gradovsky: in 9 vol.]. $\mathrm{SPb}, 1900$. Vol. 6. S. 28-106 (in Russian).

34. Gradovskij A. D. Staroe i novoe slavyanofil'stvo. Sobranie sochinenij A. D. Gradovskogo: in 9 vol. [Old and new Slavianofilstvo. Collected works by A.D. Gradovsky: in 9 vol.]. SPb, 1900. Vol. 6. S. 464472 (in Russian).

35. Gradovskij A. D. Sochineniya [Research Essays]. $\mathrm{SPb}, 2001 . \mathrm{S} .460$ (in Russian).

36. Grosul V. YA., Itenberg G. S., Tvardovskaya V. A., SHacillo K. F., Ejmontov R. G. Russkij konservatizm 
XIX stol. Ideologiya i praktika [Russian conservatism in XIX cent. Ideology and Practice]. M., 2000. 440 s. (in Russian).

37. Gulyak I. I. Social'no-politicheskaya filosofiya A. D. Gradovskogo: dis. d-ra filos. nauk. [Socio-political philosophy by A. D. Gradovsky]. SPb, 2001. 21 s. (in Russian).

38. Zamaleev A.F. A. D. Gradovskij. Veche [Gradovsky. Veche ] 1999. Vol. 12. S. 76-86. [(in Russian).

39. Ivanovskij I.A. A. D. Gradovskij kak uchenyj [A. Gradovsky as a scholar]. SPb, 1900. 13 s. (in Russian).

40. Il'in N. K 175 letiyu A. Gradovskogo [To the 175th anniversary of A. Gradovsky]. URL: http://koksheneva.ru/posts/gradovskiy/ 40 (in Russian).

41. Miller A. Istoriya ponyatiya «natsiya» v Rossii. Ponyatie o Rossii: $\mathbf{k}$ istoricheskoj semantike imperskogo perioda Русский консерватизм XIX стол. Идеология и практика [History of the concept of "nation" in Russia. Concepts of Russia: to the historical semantics of the imperial period]. M., 2012. S.7-49 (in Russian).

42. Plyashchenko T.E. Politicheskie $\mathrm{i}$ istoricheskie vzglyady A. D. Gradovskogo: avtoref. kand. istor. Nauk [Political and historical views of A.D. Gradovsky]. Voronezh, 2004. 21 s. [in Russian].
43. Sveshnikov M. Gradovskij (Aleksandr Dmitrievich). Enciklopedicheskij slovar' Brokgauza i Efrona: in 86 vol. [Gradovsky (Alexander Dmitrievich). Brockhaus Encyclopedic Dictionary and Efron: in 86 vol.]. SPb., 1890 1907. Vol. 9 a. S. 491-492 (in Russian).

44. Sementkovskij R. Mihail Katkov. Ego zhizn' i literaturnaya deyatel'nost' [Mikhail Katkov. His life and literary activity]. SPb, $1892.90 \mathrm{~s}$. (in Russian).

45. Struve P. B. Apokalipsis protiv istorii. Patriotika: Rossiya. Rodina. [Apocalypse against history. Patriotics: Russia. Homeland. Strange Land]. SPb, 2000. 352 s. (in Russian).

46. Firsov S.L. Religioznaya politika i narodnoe blagochestie v Rossii (1825-1861). Cerkov' i vremya. Nauchno-bogoslovskij i cerkovno-obshche stvennyj zhurnal [Religious policy and popular piety in Russia (18251861). Church and time. Scientific-theological and churchsocial journal]. Vol. 1 (30). M., 2005. S. 200-204 (in Russian).

47. Fojnickij I.YA., Korkunov N.M., Koni A.F. Pamyati A. D. Gradovskogo [In memory of Gradovsky]. SPb, 1890. 47s. (in Russian). 